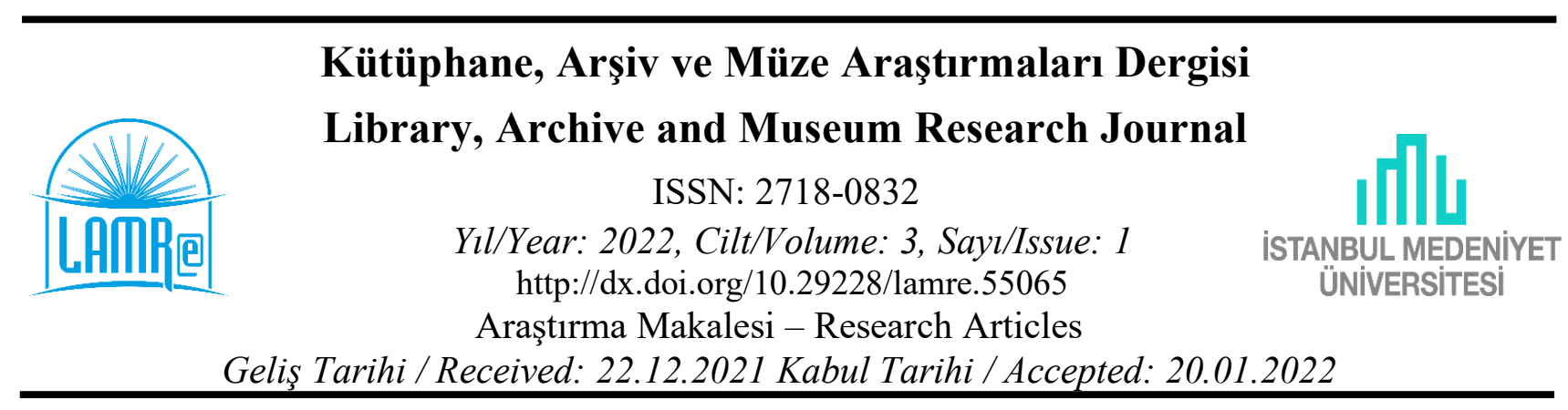

\title{
COVID-19 ve Üniversite Kütüphanelerinin Twitter Kullanımı
}

\author{
COVID-19 and University Libraries' Use of Twitter
}

\author{
Pervin BEZIRCI* (i), Bahar BİÇEN ARAS**(i)
}

\begin{abstract}
ÖZET
Bilişim devrimi bilgiye erişim alanında kütüphanelerin çalışma metotlarını dönüştürmekle kalmamış, bilgiye erişim sistemleri olarak da görülebilecek portalların, arama motorlarının, sosyal ağların ve sosyal medyanın ortaya çıkmasını sağlamıştır. Sosyal medya kullanım oranları, bilişim çağının inşa ettiği yeni güçlerden biri olarak Dünya çapında artarak çoğalmaktadır. Bilgi kurumları olan kütüphaneler de diğer kurumlar gibi bu güç platformlarını kullanıcıları ile verimli ilişkiler kurmak için önemli ve kolay bir firsat olarak görmekte ve sosyal medyadan yararlanmaktadır.

Sosyal medya aynı zamanda afetler ve acil durumlar sırasında risk ve kriz iletişimi için etkili bir araç haline gelmiştir. İnsanların çoğunun sosyal medyayı, koronavirüs hastalığı 2019 (Covid'19) salgını sırasında yoğun şekilde bilgi aramak ve paylaşmak için kullandığı görülmektedir. Bu bağlamda çalışmada, bilişim çağının ortaya çıkardığı ve hayatımızda geniş yer kaplayan yeni güçlerden biri olan sosyal medyanın Covid'19 döneminde kütüphane etkileşimi analiz edilmeye çalışılmaktadır. Çalışma kapsamında, Dünya'dan ve Türkiye'den seçilen 5'er üniversite kütüphanesi Twitter hesaplarının iletişim aracı olarak nasıl kullanıldığı örnekleri ile anlatılmaktadır. Bu üniversite kütüphanelerinin sosyal medya aktiviteleri, kullanılan medya, içerik yüklemeleri incelenmekte ve Covid'19 karantinası sırasında sosyal medyanın kütüphanelerde hizmet sunumuna yansımaları değerlendirilmektedir.
\end{abstract}

Anahtar Kelimeler: Üniversite Kütüphaneleri, Covid'19, Pandemi, Sosyal Medya, Twitter

\begin{abstract}
The information revolution has not only transformed the working methods of libraries in the field of access to information, but also led to the emergence of portals, search engines, social networks, and social media, which can be seen as information access systems. Social media statics are increasing throughout the world as one of the new powers created by the information age. Libraries, which are information institutions, consider these power platforms as an important and easy opportunity to establish productive relations with their users and benefit from social media, just like other institutions. Social media has also become an effective tool for communication during disasters and emergencies to manage the crisis and risky situations. It seems that most of the people use social media extensively to search and share information during the coronavirus disease 2019 (Covid'19) outbreak.

In this study, the use of social media by the libraries, which is one of the new powers that emerged in the information age and occupies a large place in our lives, is tried to be analyzed in the period of Covid'19. Within the scope of the study, it is explained with samples of how Twitter accounts of five university libraries selected from Turkey and other countries, respectively. The social media activities, use of media, content uploads of these university.
\end{abstract}

Keywords: University Libraries, Covid'19, Pandemic, Social Media, Twitter

*Doç. Dr. Pervin Bezirci, İstanbul Üniversitesi, Edebiyat Fakültesi, eposta: pervinb@istanbul.edu.tr

**Kütüphane Direktörü, Bahar Biçen Aras, İstinye Üniversitesi, eposta: bahar.bicenaras@istinye.edu.tr

Library, Archive and Museum Research Journal, 2022, 3(1), 1-26 


\section{GíRIŞ}

Günümüz dünyasında her gün yeni bir değişime ve değişimlerin getirdiği sonuçlara tanık olmaktayız. Değişim artık her yerde; teknolojide, politikada, iş hayatı ve ekonomide, eğitimde... Bilgi çağında var olmak, elbette yeni firsatları ve tehditleri de beraberinde getirmektedir. Ulusal sınırların anlamsız hale geldiği günümüzde Dünya'da benzer zevk ve tercihlere sahip milyarlarca insanın yaşadığı küresel ve açık bir pazar haline gelmiştir. Küreselleşmenin bir sonucu olarak, iş hayatında rekabet her zamankinden farklı konumdadır. Küresel pazar artık sadece en iyilerin hayatta kalabileceği bir arenadır. Kütüphaneler de, küreselleşme ikliminde, bilgi toplumuna doğru attığımız bütün adımlarda en güvenilir kılavuzlardır.

Dünya, hızla ilerleyen gelişmeler sonucunda bilgi ve ileri teknoloji ağırlıklı bir sürece girerken, bilgi ve belge merkezleri olan kütüphaneler de bu gelişmelere elbette seyirci kalmamaktadır. Kütüphaneler artık, internet nesli diye anılan yeni nesil kullanıcılara, teknolojiye uygun şartlarda hizmet vermekle yüz yüze olduklarının farkına varmış durumdadır. Dolayısıyla günümüzün en popüler araçlarından biri olan sosyal medya iletişimi de akademik kütüphane hizmetlerinin yansıtılması ve kullanıcı bağlantıları için kaçınılmaz hale gelmiştir.

$\mathrm{Bu}$ bağlamda, mevcut çalışma üniversite kütüphanelerinin sosyal medyadaki varlığını ve Covid'19 salgını karşısında, sosyal medya kullanımında yapılan değişiklikler ve hizmetlere yansımalarını keşfetmeye çalışan bir araştırmadır. Çalışmanın amaçları iki yönlüdür; Dünya'dan ve Türkiye'den seçilen bazı üniversite kütüphanelerinin sosyal medya aktivitelerini, kullanılan medya, içerik yüklemeleri ve karşılaşılan zorluklar açısından değerlendirmek ve Covid'19 karantinası sırasında kütüphane hizmet sunumunu ve sosyal medya kullanımını değerlendirmek.

Çalışma kapsamında, öncelikle Covid'19 salgınının ve sosyal medya kullanımın üniversite kütüphane hizmetleri açısından önemi ve etkisine kısaca değinildikten sonra, Dünya'dan ve Türkiye'den iyi uygulama örnekleri olarak seçilen bazı üniversite kütüphanelerinin salgının başlangıcından itibaren kriz karşısında kütüphane hizmetleri için sosyal medyayı nasıl kullandıkları ve salgın krizinde sosyal medyanın kütüphane hizmetleri açısından etkisi analiz edilmeye çalışılmaktadır. Çalışma kapsamının sınırlandırılabilmesi için seçilen üniversite kütüphanelerinin sadece 'Twitter' hesapları, salgın başlangıç dönemi olan 1 Şubat 2020 - 18 Haziran 2020 tarih aralığı kapsamında takip ettiği hesaplar ve paylaşımların içeriği çerçevesinde incelenmiştir. Pandemi sürecinde Dünya'dan ve Türkiye'den 5'er üniversite kütüphanesi Twitter hesaplarının iletişim aracı olarak nasıl kullanıldığı örnekleri ile anlatılmaktadır. Çalışmada yer alan yurtdışı üniversite kütüphaneleri için “The World's Top 100 Universities " "ve “Times Higher Education²" web sayfalarından yararlanılmıştır. Yurtiçi üniversite kütüphaneleri için 3 devlet, 2

\footnotetext{
${ }^{1}$ https://www.topuniversities.com/student-info/choosing-university/worlds-top-100-universities (Ziyaret tarihi: 10 Haziran 2020)

${ }^{2}$ https://www.timeshighereducation.com/student/best-universities/best-universities-world (Ziyaret tarihi: 10 Haziran 2020)
} 
vakıf üniversitesi kütüphanesi Twitter hesapları incelenmiş, etki ölçümü ve değerlendirme için kullanıcı etkileşimi (takipçi, beğeni, görüş, yorum) araç olarak ele alınmıştır.

Covid'19 etkileri hâlâ sürmekte olduğundan, bu araştırmanın sonunda pandemi sırasında sosyal medyanın kütüphanelerdeki rolünü ele alan küresel bir çalışmayı tamamlamak zordur. Dolayısıyla bu literatür taraması, çalışılan konunun anlaşılmasını sağlamak için iki temel alanla sınırlıdır: Covid-19 başlangıç zamanlarında, özellikle bu çalışma için seçilen platform olan Twitter aracılığı ile iletişim çalışmasının önemi ve bu dönemde kütüphaneler tarafından geliştirilen girişimler.

\section{1. İnternetin Hayatımızdaki Yeri}

İnternetin ve bilgi iletişim teknolojisi araçlarının güçlü etkisi, insanların iletişim ve etkileşiminde bir artış meydana getirmiştir (Adeoye ve diğerleri, 2021). Günümüzde günlük hayatlarında internet olmadan hareket edemez hale gelmiştir. Nitekim yapılan çalışmalar internetin hayatımızdaki kapsamının giderek artıı̆ııı göstermektedir.

Ocak 2021 itibari ile Dünya çapında 4,66 milyar aktif internet kullanıcısı bulunmaktadır. Bu, küresel nüfusun \%59,5'ine denk gelmektedir. Ayrıca aktif internet kullanıcılarının \%92,6's1 (4,32 milyar) internete mobil cihazlardan erişmiştir. Dünya çapında milyarlarca insanı birbirine bağlayan internet, modern bilgi toplumunun temel direği konumundadır (Johnson, 2021).

Veriler ülkemizde de internet kullanımının gittikçe arttığını göstermektedir. Digital 2021 Turkey raporuna göre; Türkiye'de nüfusun \%90.8'i mobil bağlantıya sahip, \%77.7'si internet kullanıcısı ve \%70.8'i aktif sosyal medya kullanıcısıdır. Verilere göre 2020 ile 2021 yılları arasında Türkiye'deki internet kullanıcılarının sayısı 3,7 milyon $(+\% 6,0)$ artmıştır. Yine aynı verilere göre Türkiye'deki sosyal medya kullanıcı sayısında 6,0 milyon $(+\% 11)$ ve mobil bağlantı sayısında da 2,0 milyon $(+\% 2,7)$ artış görülmüştür. 16-64 yaş arasındaki kişilerin internet kullanmak için harcadığı zaman ortalama olarak 7 saat 57 dakika iken aynı yaş ortalamasındaki internet kullanıcılarının sosyal medyayı kullanmak için harcadığı zaman ortama 2 saat 57 dakika olarak tespit edilmiştir (Şekil 1), (Kemp, 2021).

Türkiye'de 16-64 yaş aralığında en çok kullanılan 5 sosyal medya platformu sırasıyla YouTube (\%94.6), Instagram (\%89.5), Whatsapp (\%87.5), Facebook (\%79.0) ve Twitter (\%72.5)'dır. Türkiye'de 2025 yılına kadar sosyal medya kullanıcı sayısının 73,47 milyona ulaşacağı tahmin edilmektedir (Degenhard, 2021). Statista’ya göre 2026'da aylık aktif sosyal ağ kullanıcılarının payının ülkedeki internet kullanıcılarının \%86,19'una ulaşması beklenmektedir (Statista Research Department, 2021). Data Never Sleeps 9.0'a göre günlük hayatımızı kaplayan

Library, Archive and Museum Research Journal, 2022, 3(1), 1-26 
teknoloji ve dijitalleşmenin etkisi hız kesmeden devam etmektedir. Verilere göre 2021 yılında İnternette bir dakikada; Twitter'da 575 bin tweet paylaşılmakta, Facebook'ta 240 bin fotoğraf paylaşılmakta, YouTube’ta 694 bin saatlik video izlenmekte, Zoom'da 856 dakikalık web seminerlerine ev sahipliği yapılmakta, TikTok’ta 167 milyon klip izlenmekte, Instagram'da 65 bin fotoğraf paylaş1lmaktadır (Şekil 2), (Data Never Sleeps 9.0, 2021).

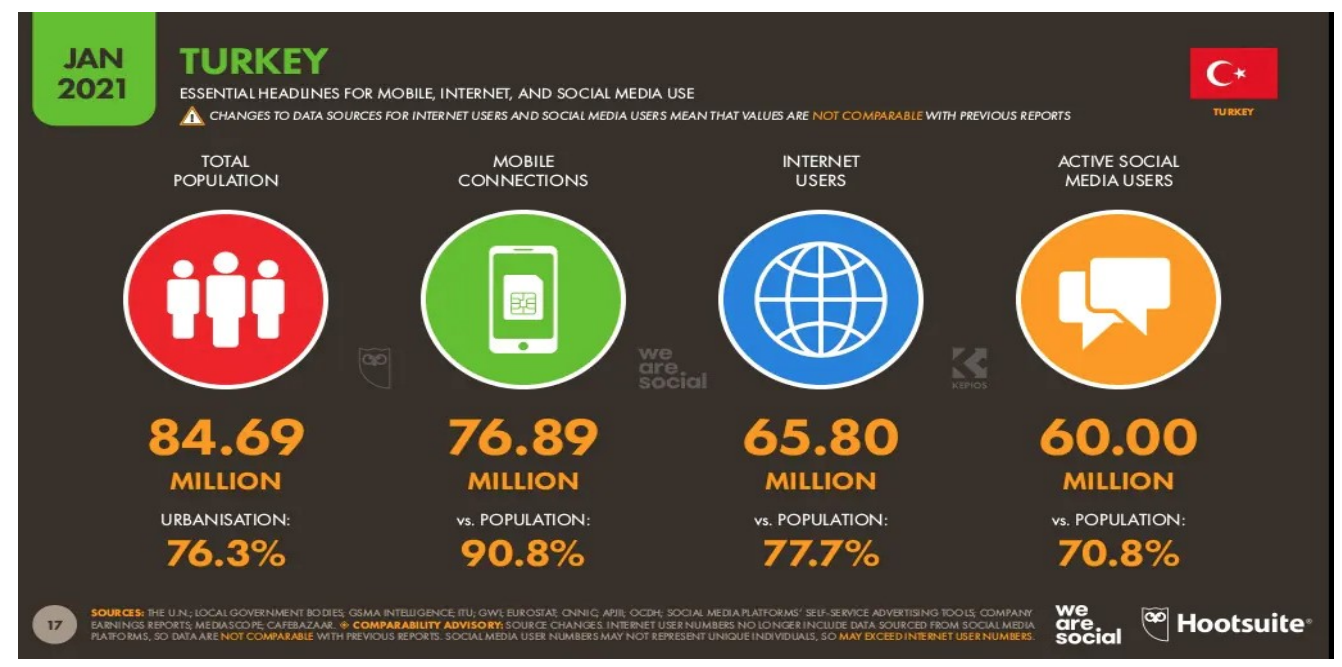

Şekil 1. Digital 2021 Turkey

Kaynak: (Digital 2021: Turkey, 2021 https://datareportal.com/reports/digital-2021-turkey)

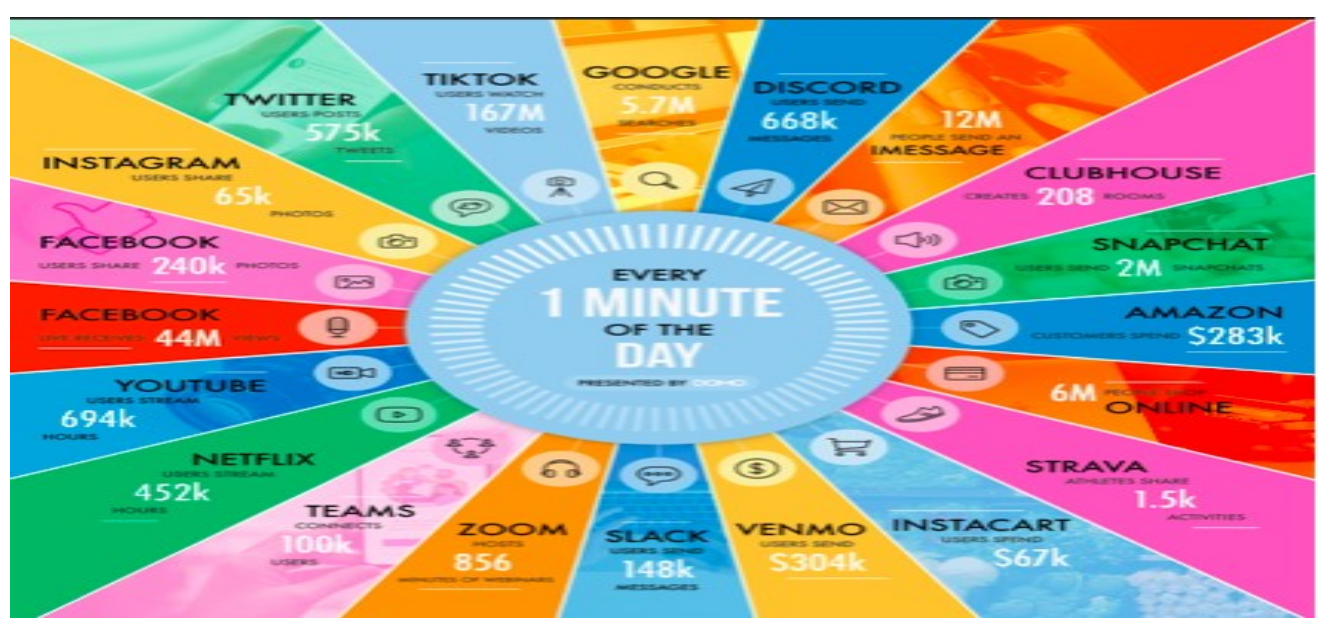

Şekil 2. Data Never Sleeps 9.0

Kaynak: (Data Never Sleeps 9.0., 2021). https://www.domo.com/learn/infographic/data-never-sleeps-9)

\section{Pandemi Krizi ve Kütüphaneler}

Krizler, beklenmeyen bir anda meydana gelen ve genellikle örgütleri hazırlıksız yakalayan durumlardır (Şahinsoy, 2017, s. 7). Covid'19'un neden olduğu sağlık krizi ve arkasından gelen karantina hizmetlerinin önemli bir bölümü yüz yüze olan birçok kurumun faaliyetlerini durdurmuştur (Martínez-Cardama ve Pacios, 2020, s. 11). Eğitim 
sektörü de hızla değişime ayak uydurmak durumunda kalmış; bir anda eğitim durmuş, öğrenciler evlerinden eğitimlerini alırken, öğretmenler de evlerinden eğitim vermeye başlamıştır.

Eğitimin, araştırmanın en önemli ayağını oluşturan kütüphanelerde de hizmetler uzaktan verilmeye başlanmıştır. Kütüphaneler, bu gerçekle başa çıkmak için etkinliklerini hızla değiştirmek zorunda kalmışlardır (Martínez-Cardama ve Pacios, 2020, s. 11). Öğretim ve eğitim faaliyetlerinin geliştirilmesinde her zaman önemli bir unsur olan üniversite kütüphaneleri karantina döneminde de önemli bir rol oynamışlar, çoğu pandemi sırasında kullanıcılar için fiziksel olarak kapalı olmasına rağmen kütüphane personeli kullanıcılar ile sürekli etkileşim halinde kalmışlardır (Martínez-Cardama ve Pacios, 2020, s. 1; Rafiq vd., 2021, s. 1). Bu dönemde kapılarını kapatan kütüphanelerin iletişim ve toplantıları sosyal medya üzerinden yapılmış, yurt içi ve yurt dışı seyahatler ile eğitimler/konferanslar iptal edilmiştir. (Arapasopo ve Adekoya, 2021, s. 6).

Üniversite kütüphaneleri araştırmayı desteklemeleri, hizmet sundukları kesimin Z kuşağı olması gibi nedenler ile teknolojiye hâkim, yeniliğe ve gelişime açı olan personeli sayesinde bu dönemde sorunların üstesinden gelebilmişlerdir. Hizmetlerini geliştirme ve sorunlara hızla çözüm bulabilme yetenekleri ile kullanıcılarının bilgi ve destek ihtiyaçlarını en kısa sürede karşılamışlardır. Danışma hizmetlerinden, satın almaya ve satın alınan basılı yayınların işlemlerinin yapıldığı teknik hizmetler birimine kadar pek çok hizmet uzaktan verilmeye başlanmıştır. Yaşanan bu değişimin kullanıcılara aktarılması, kullanıcılar tarafından doğru algılanması, verilen hizmetlerin belli bir kalitede olabilmesi için iyi bir iletişim stratejisine ihtiyaç duyulmuştur. Z kuşağı araştırmacıları sorunlarına anında çözüm arayıp, cevap beklerken klasik iletişim yöntemleri onlar için hantal kalmaktadır. Bu nedenle pandemi döneminde geleneksel iletişim araçlarından farklı olarak sosyal medya araçlarının etkin kullanımının ne kadar önemli olduğu bir kez daha anlaşılmıştır.

İnternet devrimi bilgi erişim alanında sadece kütüphaneleri iş modellerini dönüştürmekle kalmamış, İnternet bağlantılı kişisel bilgisayarlar veya mobil iletişim olanaklarıyla donanmış iletişim cihazları da birer bireysel bilgi erişim aracı haline gelerek, küresel ölçekli bilgi erişim sistemleri olarak da görülebilecek portalların, arama motorlarının ve sosyal ağlar ile sosyal medyanın ortaya çıkmasını sağlamıştır (Arıkan, 2009, s. 17).

\section{Pandemi Krizi ve Sosyal Medyanın Etkisi}

Kriz ortamında hızlı bir şekilde gerekli önlemleri alıp çözüm üretmek, hizmet verilen kesime durumu en iyi şekilde açıklayabilmek kriz ortamından rahatlık ile çıkabilmeyi sağlamaktadır. Geleneksel iletişim ve haberleşme yöntemleri (televizyon, gazete, dergi vb.) günümüzde İnternet tabanlı olarak yapılmakta, gelenekselliğin hantallığ yerini hıza bırakmaktadır. Bu sebeple kriz iletişiminde internet ve sosyal medya kullanımı son derece önemlidir (Yanık ve Becan, 2019, s. 72).

Library, Archive and Museum Research Journal, 2022, 3(1), 1-26 
Sosyal medya bireysel ya da kurumsal olarak katılımı ve etkileşimi mümkün kılan bir platformdur; kullanıcıların başkalarıyla etkileşim kurmasını sağlayan Web 2.0 teknolojisidir. Bu nedenle, katılım veya etkileşim, sosyal medya dünyasının ana odak noktasıdır (Hollebeek, 2013; Muñoz-Expósito ve diğerleri, 2017; Choi ve Kim, 2021, s. 725-726). Son yıllarda Twitter, Facebook, Weibo, Zhihu ve diğer sosyal medya platformları hızla gelişmiş ve sosyal medya kullanıcı sayısı istikrarlı bir şekilde artmıştır. Bunun sonucu olarak sosyal medya kullanımı günlük yaşamın giderek daha önemli bir parçası haline gelmiştir ve böylece sosyal medya bilginin üretilme, kullanılma ve paylaşılma şeklini önemli ölçüde değiştirmiştir (Liu ve diğerleri, 2021; Shabani ve Keshavarz, 2021).

Son y1llarda bireylerin kurumlar ile olan ilişkilerini yeni medya üzerinden gerçekleştirmeyi tercih etmesi, yeni medyanın sahip olduğu özellikler ile bağlantılıdır ve bu özellikler kurumlar ile hedef kitleler arasındaki ilişkilerin çift yönlü iletişim esasına dayanmasını, diyalog ile etkileşim odağında gerçekleşmesini ve diyalojik iletişime uygun hale gelmesini mümkün kılmaktadır (Boztepe Taşkıran, 2021, s. 17). Kişilere ya da kurumlara ait olan sosyal medya hesapları üzerinden mesajlar paylaşılmakta, cevaplar alınmaktadır. Buradan yapılan paylaşımların etki alanı geniştir. Kurumların ya da kişilerin oturduğu yerden dünyanın herhangi bir yerinde bulunan kurum ya da kişiler ile rahatlıkla iletişime geçmeye ve etkileşim halinde olmasına olanak sağlamaktadır. Özgür bir şekilde kendini ifade edebilme olanağına sahip olan kurumlar ya da kişiler için sosyal medya neredeyse olmazsa olmaz durumuna gelmiştir. Sosyal medya aynı zamanda afetler ve acil durumlar sırasında risk ve kriz iletişimi için etkili bir araç olarak ortaya çıkmıştır ve bireyler duygusal destek almanın yanı sıra kritik durumlar hakkında güncel bilgiler aramak için sosyal medyaya yönelmektedir. Son araştırmalar, insanların sosyal medyayı Covid'19 salgını sırasında benzersiz bir şekilde bilgi aramak ve paylaşmak için kullandığını göstermektedir (Erikson, 2018; Valentini ve diğerleri, 2017; Li ve diğerleri, 2020; Koulouris, 2021, s. 20). Covid'19 sırasında sosyal medya araçları, pandemi krizi hakkında temel bilgi kaynakları haline gelmiştir (Naeem ve Bhatti, 2020; Martzoukou, 2021, s. 271).

Covid'19 krizi ve kütüphanelerin geçici olarak kapanması sırasında sosyal medya, kullanıcılar ile aktif iletişimde kalmanın neredeyse tek yolu olmuş; kullanıcı talep, ihtiyaç ve isteklerini yerine getirmek ve pazarlama için sanal bir ortam oluşmuş, Facebook, Twitter, WhatsApp, MySpace, WeChat, QQ, Instagram ve LinkedIn gibi bir dizi medya, uzak kütüphane kullanıcıları ile etkileşim aracı haline gelmiştir (Kahmann ve Fingerle, 2021; Muhammad ve Zhiwei, 2021). Covid'19 nedeni ile fiziksel mekân kapanışlarına rağmen, hizmetlerini sürdürmek amacı ile, akademik kütüphaneler güncel olaylar ile ilgili belge ve bilgilere, kritik ve zamanında erişimi kolaylaştırmak için sosyal medya platformlarını etkin olarak kullanmıştır (Sobré-Denton, 2015; Mnzava, 2021, s. 8). 


\section{4. Üniversite Kütüphanesi Hizmetlerinde Sosyal Medyanın Etkisi}

Bilgi teknolojisinin en etkili kullanıldığı alanlardan biri olan kütüphanelerin, yenilikçi iletişim ve bilgiye erişim yolları ile kullanıcı beklentilerini karşılamak için yeni roller benimsemeleri gerekmektedir (Mnzava, 2021, s. 9). Yeni iletişim yollarından biri olan, sosyal medya sayesinde kütüphaneler bilgiye erişim yollarını, bilginin paylaşımını, halkla ilişkilerini; kullanıcılar ise istek ve düşüncelerini kolaylıkla anlatabildikleri, soru sordukları, kütüphaneye ait bilgi ve kaynakları paylaşabildikleri ortamlar edinmektedirler ve paylaşılan gönderiler yalnızca kullanıcı etkileşimi sağlamakla kalmayıp aynı zamanda kütüphanelerin gerçekleştirdiği etkinliklere ilişkin verilerin depolanmasını da sağlamaktadır (Biçen Aras ve Çolaklar, 2013, s. 193 ; Çakmak ve Eroğlu, 2020, s. 619). Sosyal medya, araştırmacıların zaman ve mekândan bağımsız olarak iletişim kurmalarını ve etkileşimde bulunmalarını sağlaması nedeni ile akademik alanda ve araştırmacılar arasında popüler durumdadır. Sosyal medyanın iş birlikçi faaliyetler ve özellikle araştırma için etkili bir araç olduğu düşünülmektedir (Adeoye ve diğerleri, 2021).

Sosyal medya pazarlama ve iletişim kanalı olarak kullanılan hizmetlerden biridir ve sosyal medyanın iletişimde zaman ve mekân sınırını ortadan kaldırma, geniş hedef kitleler ile düşük maliyet ile ve hızlı biçimde iletişim kurma ve iletişim faaliyetlerini diyalog ve etkileşim esasına göre şekillendirmede önemli bir kapasiteye sahip olduğuna dikkat çekilmektedir (Boztepe Taşkıran, 2021, s.28). Sosyal medyanın kullanımı dinamik ve sürekli bir iletişim stratejisi belirlemeyi gerektirir ve dinamik bir yapıya sahip olan halkla ilişkiler çalışmalarında etkin olarak kullanılabilir. Günümüzde kitle iletişim araçlarının zirvesine çıkan sosyal medyanın etkili kullanımı bilgi kaynaklarına ve/veya arşivlere erişim oranını da artıracaktır (Ayık, 2019, s. 58). Sosyal medya kullanımını tek yönlü iletişim ile sınırlamak takipçiler açısından etkileşimli kapasitesini azaltan bir unsurdur. Bu çerçevede takipçiler ile iki yönlü ve etkileşime dayanarak kurulan iletişim, sosyal medyanın temel amacıyken, kullanımının da bu yönde olması gerektiği düşünülmektedir (Kurt, 2021, s. 106). Bu nedenle kütüphane açısından takipçilerini dinlemek, onlara sorular sormak, onların görüşlerini almak iletişimin başarılı olarak kurulmasını sağlayacaktır.

Üniversite kütüphanelerinin hizmet sunduğu öğrencilerin $\mathrm{Y}$ ve $\mathrm{Z}$ kuşağına mensup olduğu düşünüldüğünde iletişim için kullanılacak en iyi yöntemlerden birinin sosyal medya olduğunu söyleyebiliriz. Z Kuşağı, doğumundan itibaren dijital olarak bağlanan küresel bir nesildir. Yapılan araştırmalara göre Z kuşağının çoğu (\%71) her gün sosyal medyada bir saatten fazla zaman harcamaktadır. Z kuşağının \% 74'ü boş zamanlarını çevrim içi geçirdiklerini söylemekte ve \%66'sı aynı anda birden fazla bağlı cihaz kullandığını bildirmektedir. Ayrıca Z kuşağının akıllı telefon merkezli olduğunu ve neredeyse dörtte üçünün akıllı telefonlarını bilgisayarlardan veya diğer cihazlardan daha sık kullandığını göstermektedir (Sy ve Chen, 2021).

Library, Archive and Museum Research Journal, 2022, 3(1), 1-26 
Bilginin internet üzerinden aktığı günümüz koşullarında sosyal medya neredeyse tüm bireyleri ağa bağlı vatandaşlar haline dönüştürmüştür (Boztepe Taşkıran, 2021, s. 18). Çok sayıda insanı tek bir noktada buluşturan sosyal medya platformları, üniversitelerin hedef kitlesi ile doğrudan iletişime geçmesinin yanı sıra, geri bildirimlerin de daha hızlı bir şekilde cevaplanmasına olanak sunmaktadır (Samur, 2020, s. 437).

Pryce ve arkadaşlarının yaptığı çalışmaya göre Covid'19 sırasında çevrim içi kütüphane oturumlarına öğrenci katılımını artırmak için kullanılan en popüler yolun sosyal medya platformları olduğunu ortaya koymuştur (Pryce ve diğerleri, 2021, s. 13). Sanal bağlantı ile sınırlı ve evlerinde sıkışıp kalmaktan sıkılan birçok kişi, paylaşmak, etkileşim kurmak, bilgilendirmek, öğrenmek ve eğlendirmek; kütüphaneler kullanıcılarla bağlantı kurmak, milyarlarca insana bilgi pazarlamak, gruplara veya bireylere kişiselleştirilmiş bilgi kaynakları sunmak için daha uygun olması nedeni ile sosyal medyaya yönelmiştir (Anderson, 2020, s. 7 ; Okike, 2020 ; Winata ve diğerleri, 2021, s. 80).

Singh'e (2017) göre sosyal medya, kütüphaneciler için birçok fayda sağlamaktadır. Bunlardan bazıları; sosyal medya kullanımının düşük maliyetidir, az eğitim gerektirir, kütüphane hizmetlerini tanıtma ve yaymada hızlıdır, kütüphane kullanııları ile etkileşimi artırır, kullanıcı hizmetlerinin kalitesini artırmak için geri bildirim toplamaya yardımcı olur, kütüphane içeriğinin kullanımını artırma potansiyeli, hem kütüphane içinde hem de diğer bölümler ile iletişimi geliştirir, kullanıcının bilgi oluşturmasına, bağlanmasına, sohbet etmesine, katkıda bulunmasına, oy vermesine ve bilgi paylaşımına izin verir, kullanıcıyı bilgi ile beslemeye yardımcı olur, öğrencilerin diğerleri arasında kütüphane kaynaklarını bulmalarına yardımcı olur (Adetayo ve williams-ilemobola, 2021).

Bunlarla birlikte sosyal medya, dijital kütüphanelerin çevrim içi koleksiyonlarını kullanıcılara tanıtmak için büyük firsatlar sağlar (Goedert, 2021, s. 195). Ayrıca akademik kütüphanelerde, bilgi ve iletişim teknolojilerinin ve sosyal medyanın kullanılması basılı koleksiyonlarındaki içeriği Covid'19 dünyasında daha erişilebilir hale getirmek için en önemli çözüm olarak görülmektedir (Bashorun ve diğerleri, 2021, s. 47).

Sosyal medya kanalları, yalnızca etkinliklerin reklamını yapmamıza ve sunduğumuz çok çeşitli bilgi ve hizmetler hakkında farkındalık yaratmamıza değil, aynı zamanda en iyi uygulamaları başkalarıyla paylaşmamıza, beğenerek ve yorum yaparak meslektaşlarımızla konuşmamıza olanak tanır. Ayrıca, diğer hizmetleri ve yerel grupları teşvik etmemize, içeriği yeniden bloklayarak veya yeniden tweetleyerek ve müşterilerimizi başka kaynaklara yönlendirerek bir topluluk yön tabelası olarak rolümüzü yerine getirmemize ve yorum ve sorular yoluyla başkalarından geri bildirim almamıza olanak tanırlar. Tüm bu işlevler, doğrudan kütüphane bilgi geleneğine uygundur (Oxford University Press, 2020). 
Ayrıca bu platformlar bilgi okuryazarlığı eğitimi konusunda kütüphanelerin etkin şekilde dijital ortamda sesini duyurmasına yardımcı olmuştur. İnternet ortamında sahte haberler/yanlış bilgi, virüsün kendisinden daha büyük bir zorluk teşkil etmekte ve kütüphaneciler sosyal medya aracılığı ile yayılan tüm sahte haberlere karşı koymak için güvenilir bilgiler paylaşmaktadır. Kütüphane, resmi olmayan bir öğrenme alanı olarak dijital ağlar ve platformlar biçimindeki yapısal sermayesini uzak topluluklara ulaşmak ve onları eğitmek için de kullanmaktadır (Chisita ve Chizoma, 2021, s. 109).

Araştırmalara göre, kütüphanelerin \%70'i küresel olarak sosyal medyayı kullanmaktadır. Kütüphane hizmetlerinin, koleksiyonlarının ve etkinliklerin düşük bir maliyetle ve iyileştirilerek kullanıcılara ulaştırılması ve onlardan geri bildirim toplanması hizmetleri kütüphaneler için sosyal medyanın en önemli faydaları olarak kabul edilmiştir. Diğer yandan sosyal medya pazarlamasında personel, beceri ve uzmanlık eksikliği ve politika eksikliği kütüphaneler tarafından sosyal medyanın benimsenmesine ilişkin birincil endişe kaynaklarıdır (Abdullah ve diğerleri, 2015; Taylor ve Francis Group, 2014).

Farklı ülkelerde sosyal medya kullanımı üzerine yapılan ampirik araştırmalar, Twitter'dan sonra Facebook'un hem kamu hem de akademik kütüphaneler tarafindan en yaygın kullanılan sosyal medya platformu olduğunu ortaya koymuştur. Akademik kütüphaneler üzerine yapılan diğer araştırmalar ortaya koymuştur ki, öğrenciler, kişisel iletişim için Facebook, YouTube ve Snapchat kullanmayı tercih ederken, kütüphaneleri takip etmek söz konusu olduğunda Facebook, Instagram ve Twitter en popüler üç platformdur. Bu bulgu açıkça kullanıcıların farklı amaçlar için farklı sosyal medya araçları seçtiklerini gösterir. Eşitsizlikler, çeşitli kullanıcılara ulaşmayı seçen sosyal medya kütüphanelerinde de tasvir edilmiştir. Facebook çoğunlukla öğrencilerle iletişim kurmak için kullanılırken, Twitter, araştırmacılar ve diğer kurumlarla bağlantı kurmak için kullanılır (Taylor ve Francis Group, 2014).

\section{5. Üniversite Kütüphanelerinde Twitter Kullanımı}

Üniversite kütüphanelerinin aktif kullandığı ve güncel paylaşımlar yaptığı Twitter ile takipçileri arasında güvenilir bir bağ oluşturmakta; kütüphaneciler, kullanıcı bilgi ihtiyaçlarını ve davranışlarını anlamanın bir başka yolu olarak Twitter üzerinden kullanıcıları ile etkileşim kurulabilmektedir (Mnzava, 2021, s. 9). Son yıllarda kütüphanelerin ve toplumun diğer sektörlerindeki artan dijitalleşme ortamı ile birlikte Twitter faaliyet miktarında da çarpıcı bir artış olmuştur (Ilyas ve diğerleri, 2021, s. 2). Twitter, kütüphane bilgilerinin ve etkinliklerinin kullanıc1lara uygun ve zamanında yayınlanmasına olanak tanımaktadır. Twitter'ın "retweet" özelliği bu tür bilgilerin kullanıcıların sosyal ağlarına daha derinlemesine yayılmasına olanak tanımakta, 'bahsetme' özelliğini kullanarak, kütüphane personeli ve bireysel kullanıcılar da konuşmalara dahil olmakta ve içeriklerini “\#konuetiketi” olarak tanımlanan 
hashtag'ler yolu ile paylaşmaları, oluşturulan içeriğin takipçilerin dışında o konu etiketini Twitter' da arayan başka kullanıcılara ulaşmasını, yaygınlaşmasını sağlayan bir araç olması nedeni ile önemli bulunmaktadır (Yang ve Ju, 2021, s. 2 ; Kurt, 2021, s. 105). Twitter, halk ile etkileşim kurmak, onları bilgilendirmek ve bir kütüphaneyi topluluk büyümesi ve gelişmesi için harika bir merkez haline getirmeye yardımcı olmak için güçlü bir araçtır (Kushniryk ve Orlovb, 2021, s. 7).

Sobré-Denton (2016), Twitter'ın kütüphanelerde uygulanmasının, kullanıcı bilgi ihtiyaçlarının anlaşılmasını geliştirerek kütüphaneciler ve kütüphane kullanıcıları arasındaki iletişimi kolaylaştırdığını ileri sürmektedir. Bununla birlikte Twitter, çok çeşitli geleneksel hizmetleri genişletmek ve kütüphane dışında bulunan çeşitli bilgileri paylaşmak için bir iletişim kanalıdır, ancak topluluk bilgilerinin paylaşılmasına ve pandemi ile ilgili bilgilerin ele alınmasına nispeten düşük bir odaklanma vardır (Choi ve Kim, 2021, s. 728-729). Kütüphane Twitter hesap incelemelerinde bu durum tespit edilmektedir.

Pandemi sırasında üniversite kütüphanelerinin, misyonlarına uygun olarak hizmetlerine devam edebilmek amacı ile kullandıkları yaratıcı çözümler ve yöntemlerden biri de, Twitter'ı etkin kullanarak kullanıcıları ile iletişimlerini güçlü tutma yöntemi olmuştur. Özellikle yurtdışı üniversite kütüphanesi örnekleri ele alındığında paylaşımlarının sistemli olduğu, eğitici, yönlendirici, eğlendirici ve kaynak kullanımına yönelik paylaşımların dikkat çektiği ve kriz yönetimine hazır oldukları görülmektedir. Pandemi ile ilgili konularda doğru bilginin kütüphane kullanıcılarına ulaşması için sistematik olarak paylaşımlar yapılmıştır.

Çalışmanın bu kısmında, pandemi sürecinde Dünya'dan ve Türkiye'den 5'er üniversite kütüphanesi seçilerek incelenmiş, Twitter hesaplarının iletişim aracı olarak nasıl kullanıldı̆̆ı örnekleri ile anlatılmıştır. Çalışmada kütüphanelerin Twitter profillerinin değerlendirmesini yapmak amacı ile takipçi sayıları, takip ettikleri diğer kullanıcıların sayısı, 1 Şubat 2020 - 18 Haziran 2020 dönemi arasında paylaştıkları tweet sayısı bilgileri kurumsal hesaplar üzerinden elde edilmiştir (Tablo 3 ve 4). Ayrıca paylaşılan tweetlerde bağlantı, fotoğraf, video gibi görsellere yer verilip verilmediği analiz edilmiştir (Tablo 5). Bununla birlikte, sosyal medya etkinliğinin ölçülmesi kolay bir iş değildir. Kullanıcı etkileşimi - örneğin bir dizi takipçi, beğeni, görüş ve yorum gibi - kütüphanelerde sosyal medya etkisini değerlendirmek için bir araç olarak önerilmiştir (Taylor ve Francis Group, 2014). Bu bağlamda, araştırma, gönderilerin içeriği ve kullanıcı katılımı arasındaki ilişkiye odaklanmıştır.

\subsection{Yurtdışı Üniversite Kütüphanelerinden Twitter Uygulama Örnekleri}

Bu kısımda yer alan yurtdışı üniversite kütüphaneleri incelenirken, Dünya'nın gelişmiş ülkelerinin en başarılı üniversitelerini sıralayan, “The World's Top 100 Universities” ve "Times Higher Education” web sayfalarından 
yararlanılmıştır. Böylece Dünya'nın farklı yerlerinden (Amerika Birleşik Devletleri, İngiltere, Kanada ve Japonya) 5 farklı üniversite kütüphanesinin pandemi sürecinde kullanıcıları ile iletişimi sağlamada attı̆ğ adımlar gösterilmeye çalışılmıştır. $\mathrm{Bu}$ üniversite kütüphaneleri sırasıyla; Massachusetts Teknoloji Enstitüsü Kütüphaneleri, Edinburgh Üniversitesi Kütüphaneleri, Toronto Üniversitesi Kütüphanesi, Cambridge Üniversite Kütüphanesi ve Waseda Üniversite Kütüphanesi’dir.

\subsubsection{Massachusetts Teknoloji Enstitüsü Kütüphaneleri}

Twitter hesab1@mitlibraries‘1 Mart 2009 tarihinde açmışlar ve aktif olarak kullanmaktadırlar. Massachusetts Teknoloji Enstitüsü Kütüphaneleri hesabının 17.900 takipçisi bulunurken, 767 hesabı takip etmektedir ${ }^{3}$. Twitter hesabından 1 Şubat 2020 - 18 Haziran 2020 tarihleri arasında toplam 411 adet paylaşım yapılmıştır. İncelenen bu paylaşımlardan 70 (\%17)'i "pandemi” ya da "Covid'19" kelimelerini içerirken, 341 (\%83) paylaşım ise genel konuları kapsamaktadır. Massachusetts Teknoloji Enstitüsü Kütüphaneleri bağlı bulunduğu kurumda yer alan diğer birimler ile etkileşim sağlayarak pandemi ile ilgili paylaşımlarda bulunmuşlardır. Kütüphane paylaşımlarını ve Retweetleri (RT); bağlantı linkleri, videolar, fotoğraflar, resimler ve hareketli resimler (gif) ile desteklemişlerdir. Covid'19 ile ilgili güncellenmiş yeni bilgi geldikçe RT yapmaya devam etmişler, kullanıcının ilgisini bu konuya çekmeye çalışmışlardır. Bu süreçte pandemi nedeni ile üniversitenin uzaktan eğitime geçmesi ile kütüphane kullanıcılarında oluşabilecek soruları cevaplayacak paylaşımlar yapılmıştır. Kullanıcıları ile bağlantıda kalmak ve kullanıcıların evlerinde kendilerini iyi hissetmesini sağlamak amacı ile paylaşımlar yapılmış, yapılan paylaşımlar ile kullanıcıların rutin uygulamalara devam etmesi sağlanmaya çalışılmıştır. Tweetlerin incelendiği dönem içinde paylaşımlarının sadece pandemi ile ilgili olmadığı tespit edilmiştir. Buna göre; kütüphanede çalışan personel bilgi paylaşımı, personel atamalarl, yeni kütüphane kaynakları, kütüphane kaynaklarına erişim ve kullanım için gerekli koşullar, Twitter takipçilerinin kütüphane ile ilgili yorum ve paylaşımları, kullanıcıların projelerine yapılacak destekler, kütüphane rehberleri, önemli kişiler, önemli olaylar, üniversite dışındaki kurumların üniversite ve pandemi ilişkisine dair paylaşımları, teşekkürleri, çevrim içi eğitimler, atölyeler, toplantılar ve dersler ile birlikte sanal dünyada artan suçlara karşı dikkat çekmek, yaşanan teknolojik sorunlara çözümler, kütüphane kaynaklarının kullanım istatistikleri, farklı kütüphaneler ile etkileşimler, kütüphanelerden haberler, iş birlikleri, değerlendirme anketleri, kütüphanenin strateji planı, mezunlara bilgiler, toplumsal olaylara duyarlılık ile ilgili farklı konu başlıklarında paylaşımlar yapıldığı görülmüştür.

\footnotetext{
${ }^{3}$ https://twitter.com/mitlibraries (Ziyaret tarihi: 18 Haziran 2020)
}

Library, Archive and Museum Research Journal, 2022, 3(1), 1-26 


\subsubsection{Edinburgh Üniversite Kütüphanesi}

Twitter hesab1@EdUniLibraries‘'1 Eylül 2014 tarihinde açmışlar ve aktif olarak kullanmaktadırlar. Edinburgh Üniversitesi Kütüphanesi hesabının 3.038 takipçisi bulunurken, 592 hesabı da takip etmektedir ${ }^{4}$. Twitter hesabından 9 Mart 2020 - 18 Haziran 2020 tarihleri arasında toplam 403 adet paylaşım yapılmıştır. İncelenen bu paylaşımlardan 33 (\%8.2)'ü “pandemi”, “karantina” ya da “Covid'19” kelimelerini içerirken, 370 (\%91.8) paylaşım genel konulardadır. Paylaşımlar yapılırken \#LibraryFromHome \#StayHomeStaySafe \#librarydatabase \#OTD \#TakeoverTuesday \#librarylife \#HereToHelp \#studentlife \#LibraryBitesize \#ResourceLists \#LibraryShelfie \#thursdaytheatre \#playsonline \#DiscoverEd \#MentalHealthAwarenessWeek \#virtuallibraries \#MentalHealthAwarenessWeek \#WeHaveGreatStuff \#Kindness \#Lyell \#WorldBookNight \#EarthDay \#NationalTeaDay \#OER \#UKOER \#letterstothelibrary \#ISGPets \#BookFaceFriday \#Dissertation \#SpecialCollections \#DissertationWeek ve \#DissertationFair etiketleri kullanılmıştır. Yine bu paylaşımlar fotoğraf, hareketli resim, video ve bağlantılar ile desteklenmiştir. Bunlar ile birlikte @EdUniMainLib ${ }^{5}$ hesabının paylaşımlarını da sık sık RT yapmışlardır. Ayrıca bağlı bulunduğu üniversite Twitter hesabı paylaşımlarını da RT yapmışlardır. Edinburgh Üniversitesi Kütüphanesi bulunduğu üniversiteye bağlı diğer birimler ile de etkileşim halinde kalarak pandemi ile ilgili paylaşımlar yapmıştır. Ülke genelinde Covid'19 ile ilgili güncellenmiş bilgi geldikçe RT yapmaya devam etmişler, kullanıcının ilgisini bu konuya çekmişlerdir. Uzaktan eğitime geçilmesi ile birlikte kütüphane kullanıcılarının merak ettiği sorulara cevaplar verilmiştir. Kullanıcıları ile bağını koparmamak ve evlerinde kendilerini iyi hissetmesini sağlamak amacı ile paylaşımlar yapılmış, yapılan paylaşımlar ile kullanıcıların rutin uygulamalara devam etmesini sağlanmaya çalışmışlardır. Tweetlerin incelendiği dönemde Twitter paylaşımlarının sadece pandemi ile ilgili olmadığı tespit edilmiştir: Kütüphanede çalışan personel bilgisi, yeni kütüphane kaynakları, kaynaklara erişim için gerekli koşullar, Twitter takipçilerinin kütüphane ile ilgili yorum ve önerileri, önemli kişiler, önemli olaylar, üniversite dışındaki kurumların üniversite ve pandemi ilişkisine dair paylaşımları, teşekkürleri, çevrim içi eğitimler, farklı kütüphaneler ile etkileşimler, kütüphanelerden haberler, toplumsal olaylara duyarlılık ile ilgili paylaşımlar gibi farklı konu başlıklarında paylaşımlar yapıldığ 1 görülmektedir.

\subsubsection{Toronto Üniversitesi Kütüphaneleri}

Twitter hesab1@uoftlibraries‘1 Ekim 2009 tarihinde açmışlar ve aktif olarak kullanmaktadırlar. Toronto Üniversitesi Kütüphanesi hesabının 8.910 takipçisi bulunurken, 646 hesabı da takip etmektedir ${ }^{6}$. Twitter hesabından 11 Mart 2020 - 18 Haziran 2020 tarihleri arasında toplam 320 adet paylaşım yapılmıştır. İncelenen bu

\footnotetext{
${ }^{4}$ https://twitter.com/EdUniLibraries (Ziyaret tarihi: 19 Haziran 2020)

${ }^{5} \mathrm{https}: / /$ twitter.com/EdUniMainLib (Ziyaret tarihi: 19 Haziran 2020)

${ }^{6}$ https://twitter.com/uoftlibraries (Ziyaret tarihi: 22 Haziran 2020)
} 
paylaşımlardan 91 (\%28.4)'i “pandemi”, "karantina” ya da “Covid'19” kelimelerini içerirken, 229 (\%71.6) paylaşım genel konulardadır. Kütüphane paylaşımlarını yaparken \#UofT \#COVID_19 \#StayHomeCanada \#COVID19 \#Toronto \#CanFilmDay \#ICYMI \#StayHome \#QuarantineHouse \#UofTGrad20 \#UofTCares \#AsianHeritageMonth etiketlerini kullanmışlardır. Tweet paylaşımlarını fotoğraf, hareketli resim, video ve bağlantılar ile desteklemişlerdir. Paylaşımlarda mizahın öne çıktığı görülmektedir. Bulundukları üniversitenin Twitter hesabı paylaşımları RT yapılmaktadır. Edinburgh Üniversitesi Kütüphanesi üniversiteye bağlı diğer birimler ile de etkileşim halinde kalarak pandemi ile ilgili paylaşım yapmışlardır. Güncellenmiş Covid'19 ile ilgili bilgileri RT yapmaya devam etmişler, takipçilerini bilgilendirmeye çalışmışlardır. Uzaktan eğitime geçmesi nedeni ile evinden kütüphane hizmeti alan kullanıcılarının merakını giderecek, sorularına cevap niteliğindeki konularda paylaşımlar yapmışlardır. Tweetlerin incelendiği dönem içinde Kütüphane paylaşımlarının sadece pandemi ile ilgili olmadığı tespit edilmiştir: Kütüphanede çalışan personel bilgisi paylaşımı, yeni kütüphane kaynakları, kaynaklara erişim için gerekli koşullar, Twitter takipçilerinin kütüphane ile ilgili yorum ve paylaşımları, önemli kişiler, önemli olaylar, üniversite dışındaki kurumların üniversite ve pandemi ilişkisine dair paylaşımları, teşekkürleri, çevrim içi eğitimler, farklı kütüphanelerle etkileşimler, kütüphanelerden haberler, toplumsal olaylara duyarlılık, devlet kurumlarının paylaşımları, istatistiki bilgiler, personel çocukları için düzenlenmiş etkinlik bilgileri, Covid'19 belirtileri, bulaşma yolları gibi bilgilerin yer aldı̆̆ı paylaşımlar gibi farklı konu başlıklarında paylaşımlar yapıldığı görülmektedir. Ayrıca Toronto Üniversitesi Kütüphanesi sosyal medya stratejisine göre; kütüphane kullanıcılarının sosyal medyayı kullanarak kütüphane ile iletişim kurulurken \#UTORlibs etiketinin kullanılmasını istemektedir ${ }^{7}$.

\subsubsection{Cambridge Üniversitesi Kütüphanesi}

Twitter hesab1@theUL'1 Mart 2009 tarihinde açmışlardır ve aktif olarak kullanmaktadırlar. Cambridge Üniversitesi Kütüphanesi hesabının 20.698 takipçisi bulunurken, 367 hesabı da takip etmektedirler ${ }^{8}$. Kütüphane Twitter hesabından 13 Mart 2020 - 18 Haziran 2020 tarihleri arasında toplam 265 adet paylaşım yapılmıştır. İncelenen bu paylaşımlardan 29 (\%10.9)'u "pandemi”, “karantina” ya da “Covid'19” kelimelerini içerirken, 236 (\%89.1) paylaşım genel konuları kapsamaktadır. Kütüphane paylaşımlarını yaparken \#CoronavirusOutbreak \#coronavirus \#covid19UK \#RisingTide \#WomenAtCambridge \#StudyingFromHome \#librarypoems \#makeyourheartsing \#wednesdayportraits \#photography \#COVID19Pandemic \#librariesfromhome \#openonline \#COVID-19 \#homeschooling \#English \#poetry \#scrabble \#quarantinereads \#books \#LibraryLife \#LoveYourLibrary \#LibraryTwitter \#NationalTeaDay \#DonQuixote \#WorldBookDay \#IndoorGamesForAwkwardMoments \#librarytwitter \#LockdownReads \#InternationalNursesDay

\footnotetext{
${ }^{7}$ https://onesearch.library.utoronto.ca/social-media (Ziyaret tarihi: 22 Haziran 2020)

8 https://twitter.com/theul (Ziyaret tarihi: 22 Haziran 2020)
} 
\#VirtualTeaRoom \#research \#cambridgeuniversitylibrary \#cambridgeuniversity \#cambridge \#library \#DCtUesdays \#digitallibrary \#digitalcontentunit \#stayhome \#wfh \#MentalHealthAwarenessWeek \#history \#WomenAtCambridge \#lockdown \#plague \#Science \#towelday \#BlackLivesMatter \#WWII \#Friday \#archive \#Mycenae \#Aramaic \#camguides \#Cambridge \#endbandthursday \#vintage \#BooksofTwitter \#librarylife \#Zoom \#angels \#Scotland \#lockdown \#zoomcalls \#UnusualItem \#Archive30 \#WhyArchives? \#MayThe4thBeWithYou \#StarWarsDay \#LightItBlue \#ThankYouNHS \#ClapForOurCarers \#DrWho \#medieval \#manuscript \#MedievalTwitter \#TomorrowIsAnotherDay \#Chinese \#birds \#China \#woodblocks \#BookofHours \#FeelingFrisket \#Gutenberg \#Bible \#TheAeronauts \#NurembergChronicle etiketlerini kullanmışlardır. Paylaşımlar fotoğraf, hareketli resim, video ve bağlantılar ile desteklenmiştir. Üniversite Twitter hesabının paylaşımları RT yapılmaktadır. Cambridge Üniversitesi bünyesinde yer alan diğer birimler ile de etkileşim halinde kalarak pandemi ile ilgili paylaşımlarda bulunmuşlardır. Gündeme ilişkin, Covid'19 ile ilgili yenilenmiş bilgi geldikçe RT yapmaya devam etmişler, kullanıcının gündemi takip etmesi sağlanmıştır. Evden eğitim alan, kütüphane ile evden iletişime geçen kullanıcılarının yeni duruma alışmaları, kafalarında oluşabilecek soruları cevaplayan içerikler paylaşmışlardır. Tweetlerin incelendiği dönem içinde Kütüphane paylaşımlarının sadece pandemi ile ilgili olmadığı tespit edilmiştir: Kütüphanede çalışan personel bilgi paylaşımı, yeni kütüphane kaynakları, kaynaklara erişim için gerekli koşullar, Twitter takipçilerinin kütüphane ile ilgili yorum ve paylaşımları, önemli kişiler, önemli olaylar, üniversite dışındaki kurumların üniversite ve pandemi ilişkisine dair paylaşımları, teşekkürleri, çevrimiçi eğitimler, farklı kütüphanelerle etkileşimler, kütüphanelerden haberler, toplumsal olaylara duyarlılık, devlet kurumlarının paylaşımları, istatistiki bilgiler, sanal sergiler, sanal turlar, el becerilerine yönelik örnekler, koleksiyonlarından ilgi çekici parçaların gösterimi, anlatımı, tarihte bugün, önemli kişiler gibi farklı konu başlıklarında paylaşımlar yapıldığı görülmektedir.

\subsubsection{Waseda Üniversitesi Kütüphanesi}

Twitter hesab1@waseda_univ_WUL‘u Mart 2013 tarihinde açmışlardır. Tweet paylaşımlarını kütüphane web sayfasında olduğu gibi hem anadili Japonca hem de İngilizce olarak yapmaktadırlar. Waseda Üniversitesi Kütüphanesi hesabının 3.373 takipçisi bulunurken, 2 hesabı takip etmektedirler ${ }^{9}$ Kütüphane Twitter hesabından 28 Şubat 2020 - 26 Mayıs 2020 tarihleri arasında toplam 48 adet paylaşım yapılmıştır. İncelenen bu paylaşımlardan 26 (\%54.2)’s1 "pandemi”, “karantina” ya da "Covid'19” kelimelerini içerirken, 22 (\%45.8) paylaşım genel konuları kapsamaktadır. Waseda Üniversitesi Kütüphanesi paylaşımlarında resmi bir dil kullanmaktadır. Paylaşımları fotoğraf ve bağlantılar ile desteklemişlerdir. Üniversite Twitter hesabının paylaşımlarını da RT yapmaktadırlar. Covid'19 ile ilgili güncellenmiş bilgileri sık sık paylaşarak kullanıcının ilgisini bu konuya çekmeye çalışmışlardır. Uzaktan eğitim ve kütüphane kullanımı ile ilgili kullanıcıların kafasında oluşabilecek

9 https://twitter.com/waseda_univ_WUL (Ziyaret tarihi: 22 Haziran 2020) 
sorulara yanıt verecek paylaşımlar yapmışlardır. Tweetlerin incelendiği dönem içinde Kütüphane paylaşımlarının sadece pandemi ile ilgili olmadığ1 tespit edilmiştir: Kütüphanedeki değişiklikler, kütüphane bülteni duyurusu, web sayfasındaki yenilikler, mezun öğrencileri bilgilendirici paylaşımlar, farklı üniversitelerle yapılan iş birlikleri, yeni kaynakların duyurulması gibi paylaşımların yapıldı̆̆ 1 tespit edilmiştir.

\subsection{Yurtiçi Üniversite Kütüphanelerinden Twitter Uygulama Örnekleri}

Yurtiçi üniversite kütüphaneleri için seçim yapılırken Türkiye'de hizmet veren, sosyal medya kullanan devlet ve vakıf üniversitelerinin hesapları incelenmiş, kullanıcıları ile iletişimde sosyal medyayı en aktif kullanan üniversiteler tespit edilmiştir. Bu çalışma kapsamında, sınırlı sayıda üniversiteye yer verilebileceğinden 3 devlet (İstanbul, Bursa ve Ankara), 2 vakıf üniversitesi (İstanbul, Ankara) kütüphanesi Twitter hesapları ele alınmıştır. Bu üniversite kütüphaneleri sırasıyla; İstanbul Üniversitesi Merkez Kütüphanesi, Bursa Uludağ Üniversitesi Prof. Dr. Fuat Sezgin Merkez Kütüphanesi, Hacettepe Üniversiteleri Kütüphaneleri, MEF Üniversitesi Kütüphanesi ve Bilkent Üniversitesi Kütüphanesi’dir.

\subsection{1. İstanbul Üniversitesi Merkez Kütüphanesi}

Twitter hesab1@iumerkezkutup Aralık 2011 tarihinde açılmıştır. İstanbul Üniversitesi Merkez Kütüphanesi hesabının 4.130 takipçisi bulunurken, 26 hesabı takip etmektedirler ${ }^{10}$. Twitter hesabından 13 Mart 2020 - 19 Mayıs 2020 tarihleri arasında toplam 26 paylaşım yapılmıştır. İncelenen bu paylaşımlarda sadece 3 (\%11.5) paylaşım “pandemi” ya da “Covid'19” kelimelerini içerirken, 23 (\%88.5) paylaşım genel konuları kapsamaktadır. İstanbul Üniversitesi Merkez Kütüphanesi bu süreçte eğitim duyurularına ağırlık vermiştir. Kendi paylaşımlarını ve Retweetleri bağlantı linkleri, videolar, fotoğraflar, resimler ile desteklemişlerdir.

\subsubsection{Bursa Uludağ Üniversitesi Prof. Dr. Fuat Sezgin Merkez Kütüphanesi}

Twitter hesab1@uludagkutuphane, Ağustos 2015 tarihinde açılmıştır. Hesabı aktif olarak kullanmaktadırlar. Bursa Uludağ Üniversitesi Prof. Dr. Fuat Sezgin Merkez Kütüphanesi hesabının 2.408 takipçisi bulunurken, 15 hesabı da takip etmektedirler ${ }^{11}$. Twitter hesabından 16 Mart 2020 - 18 Haziran 2020 tarihleri arasında toplam 162 adet paylaşım yapılmıştır. İncelenen bu paylaşımlardan 11 (\%6.8)'i “pandemi" ya da "Covid'19" kelimelerini içerirken, 151 (\%93.2) paylaşım ise genel konulardadır. Paylaşımlarını yaparken \#HomeEvdeKal \#KütüphaneSizeYeter \#uludagkutuphane \#veritabanı \#ekaynaklar \#UludagKutuphaneEvinde \#kutuphanehaftası \#KH56 \#Türkiyeokuyor etiketlerini kullanmışlardır. Paylaşımlarını fotoğraf, hareketli resim (gif), video ve

\footnotetext{
${ }^{10} \mathrm{https}$ ://twitter.com/iumerkezkutup (Ziyaret tarihi: 22 Haziran 2020)

${ }^{11}$ https://twitter.com/uludagkutuphane (Ziyaret tarihi: 22 Haziran 2020)
} 
bağlantılar ile desteklemişlerdir. İstatistiki bilgiler, kaynak tanıtımı ve çevrim içi eğitimler sık sık paylaşılmıştır. Rektörlüğün kütüphane ile ilgili paylaşımları RT edilmiş, kullanıcının dikkati kütüphaneye çekilmeye çalışılmıştır.

\subsubsection{Hacettepe Üniversitesi Kütüphaneleri}

Twitter hesab1@hukutuphaneleri, Ekim 2010 tarihinde açılmıştır. Hacettepe Üniversitesi Merkez Kütüphanelerinin 1.418 takipçisi bulunurken, 26 hesabı takip etmektedirler ${ }^{12}$. Twitter hesabından 16 Mart 2020 15 Haziran 2020 tarihleri arasında toplam 65 adet paylaşım yapılmıştır. İncelenen bu paylaşımlardan 10 (\%15.4)'u “pandemi” ya da “Covid'19” kelimelerini içerirken, 55 (\%84.6) paylaşım ise genel konulardadır. Paylaşımlarını yaparken \#kütüphane \#veritabani \#koronavirus \#hacettepe \#Nekadarönlemokadarkorunma \#coronavirus \#ekitap \#ebook \#onlineegitim \#evdekal etiketlerini kullanmışlardır. Paylaşımlarını fotoğraf, hareketli resim (gif), video ve bağlantılar ile desteklemişlerdir. Kütüphane kullanımı, kaynak tanıtım, çevrimiçi eğitimler, önemli günler ve virüs ile ilgili paylaşımlar sık sık paylaşılmıştır.

\subsubsection{MEF Üniversitesi Kütüphanesi}

Twitter hesab1@MEFKutuphane, Kasım 2014 tarihinde açılmıştır. MEF Üniversitesi Kütüphanesi hesabının 1.269 takipçisi bulunurken, 23 hesabı da takip etmektedirler ${ }^{13}$. Twitter hesabından 11 Mart 2020 - 17 Haziran 2020 tarihleri arasında toplam 92 adet paylaşım yapılmıştır. İncelenen bu paylaşımlardan $9(\% 9.8)$ 'u "pandemi” ya da “Covid'19” kelimelerini içerirken, 83 (\%90.2) paylaşım ise genel konulardadır. Paylaşımlarını yaparken \#MEFKütüphaneUzaktanErişim \#BilgiyeSinırsızErişim \#EvdeKal \#MEFÜniversitesi \#ÖğrenmeyeSınırsızÖzgürlük \#KaynakPaylaşımı \#IFLA \#COVID-19 \#MEFKütüphane \#OnlineEğitim \#Anket etiketlerini kullanmışlardır. Paylaşımlarını fotoğraf, hareketli resim (gif), video, bağlantı ve anketler ile desteklemişlerdir. Kütüphane kullanımı, kaynak tanıtımı, çevrim içi eğitimler, önemli günler, kullanıcı görüşleri, kardeş kurumlarla iş birlikleri, kütüphane personelinden haberler, elde edilen başarılar, farklı kurumlarla iş birlikleri ve virüs ile ilgili konular paylaşılmıştır.

\subsubsection{Bilkent Üniversitesi Kütüphanesi}

Twitter hesab1@librarybilkent, Ocak 2014 tarihinde açılmıştır. Bilkent Üniversitesi Kütüphanesi hesabının 1.991 takipçisi bulunurken, 175 hesabı da takip etmektedirler ${ }^{14}$. Twitter hesabından 18 Mart 2020 - 15 Haziran 2020 tarihleri arasında toplam 34 adet paylaşım yapılmıştır. İncelenen bu paylaşımlardan 6 (\%17.6)'s1 “pandemi” ya da "Covid'19" kelimelerini içerirken, 28 (\%82.4) paylaşım ise genel konulardadır. Bilkent Üniversitesi

\footnotetext{
12 https://twitter.com/hukutuphaneleri (Ziyaret tarihi: 22 Haziran 2020)

13 https://twitter.com/MEFKutuphane (Ziyaret tarihi: 22 Haziran 2020)

${ }^{14}$ https://twitter.com/librarybilkent (Ziyaret tarihi: 23 Haziran 2020)
} 
Kütüphanesi paylaşımlarında resmi dil Türkçe yanında İngilizce’yi de kullanmaktadır. Paylaşımlarını yaparken \#stayathome \#OkumakDeğiştirir \#EvdeKitapOkuyorum \#KitapOkuyoruz2020 \#KütüphaneHaftasl2020 etiketlerini kullanmışlardır. Paylaşımlarını fotoğraf, video ve bağlantılar ile desteklemişlerdir. Kütüphane kullanımı, kaynak tanıtımı, çevrim içi eğitimler, önemli günler, kütüphane personelinden haberler, farklı kurumlarla iş birlikleri ve pandemi ile ilgili konular paylaşılmıştır. Paylaşımlarını yaparken diğer sosyal medya araçları ile bağlantılar kurmuşlardır. Bu paylaşımlara Facebook hesabı ve Instagram hesabı örnek gösterilebilir.

\subsection{Genel Değerlendirme}

Dünya'dan ve Türkiye'den 10 Üniversite kütüphanesi Twitter hesaplarından toplam 1.826 İngilizce, Türkçe ve Japonca tweet incelenmiştir. Yurtdışı üniversite kütüphanelerinin incelenen tweet sayıs1 1.447, Türkiye'den üniversite kütüphanelerinin incelenen tweet say1s1 ise 378'dur (Tablo 1). Yine bu twitlerin 288'i pandemi kelimesini içermektedir. 1.538 'i dolaylı olarak pandemi ve genel konuları kapsamaktadır (Tablo 2). Ele alınan 10 kütüphanenin Twitter hesaplarında paylaşılan tweetlerin içerikleri şu konuları kapsamaktadır: Covid'19 paylaşımı/duyuruları, bilimsel toplantılar, akademik ve bilimsel başarılar, öğrenci çalışmaları ve etkinlikleri, açılan yeni bir bölüm haberi, yeni hizmetler ve teknolojik gelişmeler, kütüphane duyuruları, kullanıcıları bilgilendirici notlar, toplumsal ve güncel olaylar, sanatsal ve mizahi paylaşımlar, kullanıcı eğitimleri, memnuniyet anketleri, görüş ve öneriler, kullanıcı paylaşımları, kültürel etkinlikler, kütüphanecilerden/personelden haberler, istatistikler (Tablo 6).

Tablo 1. 1 Şubat 2020-18 Haziran 2020 Arası Tweet Sayıları

\begin{tabular}{|c|c|c|}
\hline $\begin{array}{c}\text { Yurtdışı } \\
\text { Kütüphaneleri } \\
\text { Tweet Sayısı }\end{array}$ & $\begin{array}{c}\text { Yurtiçi } \\
\text { Kütüphaneleri } \\
\text { Tweet Sayısı }\end{array}$ & $\begin{array}{c}\text { Toplam } \\
\text { Tweet } \\
\text { Sayısı }\end{array}$ \\
\hline 1.447 & 379 & 1.826 \\
\hline
\end{tabular}

Tablo 2. 1 Şubat 2020-18 Haziran 2020 Arası Paylaşım Türü

\begin{tabular}{|c|c|c|}
\hline $\begin{array}{c}\text { Doğrudan } \\
\text { Pandemi } \\
\text { Kelimesini } \\
\text { İçeren } \\
\text { Paylaşımlar }\end{array}$ & $\begin{array}{c}\text { Diğer } \\
\text { Konuları } \\
\text { Kapsayan } \\
\text { Paylaşımlar }\end{array}$ & $\begin{array}{c}\text { Toplam } \\
\text { Tweet } \\
\text { sayısı }\end{array}$ \\
\hline 288 & 1.538 & 1.826 \\
\hline
\end{tabular}

Library, Archive and Museum Research Journal, 2022, 3(1), 1-26 
Tablo 3. Yurtdışı Üniversite Kütüphaneleri Twitter Hesabı Analizi (1 Şubat 2020-18 Haziran 2020)

\begin{tabular}{|c|c|c|c|c|c|c|c|c|}
\hline Kütüphane & Twitter Hesabı & $\begin{array}{l}\text { Hesabı } \\
\text { Oluşturma } \\
\text { Tarihi }\end{array}$ & $\begin{array}{c}\text { Takipçi } \\
\text { Sayısı }\end{array}$ & $\begin{array}{l}\text { Takip } \\
\text { Ettiği } \\
\text { Hesap } \\
\text { Sayısı }\end{array}$ & $\begin{array}{c}\text { Tarih } \\
\text { Aralığ }\end{array}$ & $\begin{array}{l}\text { Tweet } \\
\text { Sayısı }\end{array}$ & $\begin{array}{c}\text { Paylaşım } \\
\text { İçeriği } \\
\text { "Pandemi" } \\
\text { "Karantina" } \\
\text { "Covid'19" }\end{array}$ & $\begin{array}{l}\text { Paylaşım } \\
\text { İçeriği } \\
\text { "Genel } \\
\text { Konular" }\end{array}$ \\
\hline $\begin{array}{l}\text { Massachusetts } \\
\text { Teknoloji } \\
\text { Enstitüsü } \\
\text { Kütüphaneleri }\end{array}$ & (a)mitlibraries & Mar.09 & 17.900 & 767 & $\begin{array}{c}1 \text { Şubat } \\
- \\
18 \\
\text { Haziran } \\
2020 \\
\end{array}$ & 411 & $70(\% 17)$ & $341(\% 83)$ \\
\hline $\begin{array}{l}\text { Edinburgh } \\
\text { Üniversite } \\
\text { Kütüphanesi }\end{array}$ & $@$ EdUniLibraries & Eyl.14 & 3.038 & 592 & $\begin{array}{c}9 \text { Mart } \\
- \\
18 \\
\text { Haziran } \\
2020 \\
\end{array}$ & 403 & $33(\% 8.2)$ & $\begin{array}{c}370 \\
(\% 91.8)\end{array}$ \\
\hline $\begin{array}{c}\text { Toronto } \\
\text { Üniversitesi } \\
\text { Kütüphaneleri }\end{array}$ & (a)uoftlibraries & Eki.09 & 8.910 & 646 & $\begin{array}{c}11 \text { Mart } \\
- \\
18 \\
\text { Haziran } \\
2020\end{array}$ & 320 & $91(\% 28.4)$ & $\begin{array}{c}229 \\
(\% 71.6)\end{array}$ \\
\hline $\begin{array}{c}\text { Cambridge } \\
\text { Üniversitesi } \\
\text { Kütüphanesi }\end{array}$ & @theUL & Mar.09 & 20.698 & 367 & $\begin{array}{c}13 \text { Mart } \\
- \\
18 \\
\text { Haziran } \\
2020 \\
\end{array}$ & 265 & $29(\% 10.9)$ & $\begin{array}{c}236 \\
(\% 89.1)\end{array}$ \\
\hline $\begin{array}{c}\text { Waseda } \\
\text { Üniversitesi } \\
\text { Küttüphanesi }\end{array}$ & @waseda_univ_wUL & Mar.13 & 3.373 & 2 & $\begin{array}{c}28 \text { Şubat } \\
- \\
26 \text { Mayis } \\
2020\end{array}$ & 48 & $26(\% 54.2)$ & $22(\% 45.8)$ \\
\hline
\end{tabular}

Tablo 4. Yurtiçi Üniversite Kütüphaneleri Twitter Hesabı Analizi (1 Şubat 2020-18 Haziran 2020)

\begin{tabular}{|c|c|c|c|c|c|c|c|c|}
\hline Kütüphane & Twitter Hesabı & $\begin{array}{c}\text { Hesabı } \\
\text { Oluşturma } \\
\text { Tarihi }\end{array}$ & $\begin{array}{l}\text { Takipçi } \\
\text { Sayısı }\end{array}$ & $\begin{array}{l}\text { Takip } \\
\text { Ettiği } \\
\text { Hesap } \\
\text { Sayısı }\end{array}$ & $\begin{array}{c}\text { Tarih } \\
\text { Aralığg }\end{array}$ & $\begin{array}{l}\text { Tweet } \\
\text { Sayısı }\end{array}$ & $\begin{array}{c}\text { Paylaşım } \\
\text { İçeriği } \\
\text { "Pandemi" } \\
\text { "Karantina" } \\
\text { "Covid'19" }\end{array}$ & $\begin{array}{l}\text { Paylaşım } \\
\text { İçeriği } \\
\text { "Genel } \\
\text { Konular" }\end{array}$ \\
\hline $\begin{array}{c}\text { İstanbul } \\
\text { Üniversitesi } \\
\text { Merkez } \\
\text { Kütüphanesi }\end{array}$ & @iumerkezkutup & Ara.11 & 4.130 & 26 & $\begin{array}{c}13 \text { Mart } \\
- \\
19 \text { Mayis } \\
2020\end{array}$ & 26 & $3(\% 11.5)$ & $23(\% 88.5)$ \\
\hline $\begin{array}{l}\text { Bursa Uludă̆ } \\
\text { Üniversitesi } \\
\text { Prof. Dr. Fuat } \\
\text { Sezgin Merkez } \\
\text { Kütüphanesi }\end{array}$ & @uludagkutuphane & Ağu.15 & 2.408 & 15 & $\begin{array}{c}16 \text { Mart } \\
- \\
18 \text { Haziran } \\
2020\end{array}$ & 162 & $11(\% 6.8)$ & $151(\% 93.2)$ \\
\hline $\begin{array}{c}\text { Hacettepe } \\
\text { Üniversitesi } \\
\text { Kütüphaneleri }\end{array}$ & @hukutuphaneleri & Eki.10 & 1.418 & 26 & $\begin{array}{c}16 \text { Mart } \\
- \\
15 \text { Haziran } \\
2020\end{array}$ & 65 & $10(\% 15.4)$ & $55(\% 84.6)$ \\
\hline $\begin{array}{c}\text { MEF } \\
\text { Üniversitesi } \\
\text { Kütüphanesi }\end{array}$ & @MEFKutuphane & Kas.14 & 1.269 & 23 & $\begin{array}{c}11 \text { Mart } \\
- \\
17 \text { Haziran } \\
2020\end{array}$ & 92 & $9(\% 9.8)$ & $83(\% 90.2)$ \\
\hline $\begin{array}{c}\text { Bilkent } \\
\text { Üniversitesi } \\
\text { Kütüphanesi }\end{array}$ & @librarybilkent & Oca.14 & 1.991 & 175 & $\begin{array}{c}18 \text { Mart } \\
- \\
15 \text { Haziran } \\
2020\end{array}$ & 34 & $6(\% 17.6)$ & $28(\% 82.4)$ \\
\hline
\end{tabular}


Tablo 5. Yurtdış1-Yurtiçi Üniversite Kütüphaneleri Twitter İçerikleri (1 Şubat 2020-18 Haziran 2020)

\begin{tabular}{|c|c|c|c|c|c|}
\hline $\begin{array}{c}\text { Yurtdışı } \\
\text { Üniversitesi } \\
\text { Kütü̈phaneleri }\end{array}$ & $\begin{array}{c}\text { \#Etiket } \\
\text { Kullanımı }\end{array}$ & $\begin{array}{c}\text { İçerik } \\
\text { "Bağlantı } \\
\text { linkleri, } \\
\text { Videolar, } \\
\text { Fotoğraflar } \\
\text { Resimler, } \\
\text { Hareketli } \\
\text { resimler } \\
\text { (gif)" } \\
\end{array}$ & $\begin{array}{c}\text { Yurtiçi } \\
\text { Üniversite } \\
\text { Kütüphaneleri }\end{array}$ & $\begin{array}{c}\text { \#Etiket } \\
\text { Kullanımı }\end{array}$ & $\begin{array}{c}\text { İçerik } \\
\text { "Bağlantı } \\
\text { linkleri, } \\
\text { Videolar, } \\
\text { Fotoğraflar } \\
\text { Resimler, } \\
\text { Hareketli } \\
\text { resimler } \\
\text { (gif)" } \\
\end{array}$ \\
\hline $\begin{array}{l}\text { Massachusetts } \\
\text { Teknoloji } \\
\text { Enstitüsü } \\
\text { Kütüphaneleri }\end{array}$ & Hayır & $\begin{array}{l}\text { Bağlantı } \\
\text { linkleri } \\
\text { Videolar } \\
\text { Fotoğraflar } \\
\text { Resimler } \\
\text { Hareketli } \\
\text { resimler (gif) }\end{array}$ & $\begin{array}{c}\text { İstanbul } \\
\text { Üniversitesi } \\
\text { Merkez } \\
\text { Kütüphanesi }\end{array}$ & Hayır & $\begin{array}{l}\text { Bağlantı } \\
\text { linkleri } \\
\text { Videolar } \\
\text { Fotoğraflar } \\
\text { Resimler }\end{array}$ \\
\hline $\begin{array}{l}\text { Edinburgh } \\
\text { Üniversite } \\
\text { Kütüphanesi }\end{array}$ & Evet & $\begin{array}{l}\text { Bağlantı } \\
\text { linkleri } \\
\text { Videolar } \\
\text { Fotoğraflar } \\
\text { Hareketli } \\
\text { resimler (gif) }\end{array}$ & $\begin{array}{c}\text { Bursa Uludă } \\
\text { Üniversitesi } \\
\text { Prof. Dr. Fuat } \\
\text { Sezgin } \\
\text { Merkez } \\
\text { Kütüphanesi }\end{array}$ & Evet & $\begin{array}{l}\text { Bağlantı } \\
\text { linkleri } \\
\text { Videolar } \\
\text { Fotoğraflar } \\
\text { Hareketli } \\
\text { resimler (gif) }\end{array}$ \\
\hline $\begin{array}{c}\text { Toronto } \\
\text { Üniversitesi } \\
\text { Kütüphaneleri }\end{array}$ & Evet & $\begin{array}{c}\text { Bağlantı } \\
\text { linkleri } \\
\text { Videolar } \\
\text { Fotoğraflar } \\
\text { Hareketli } \\
\text { resimler (gif) } \\
\end{array}$ & $\begin{array}{c}\text { Hacettepe } \\
\text { Üniversitesi } \\
\text { Kütüphaneleri }\end{array}$ & Evet & $\begin{array}{c}\text { Bağlantı } \\
\text { linkleri } \\
\text { Videolar } \\
\text { Fotoğraflar } \\
\text { Hareketli } \\
\text { resimler (gif) }\end{array}$ \\
\hline $\begin{array}{c}\text { Cambridge } \\
\text { Üniversitesi } \\
\text { Kütüphanesi }\end{array}$ & Evet & $\begin{array}{l}\text { Bağlant1 } \\
\text { linkleri } \\
\text { Videolar } \\
\text { Fotoğraflar } \\
\text { Hareketli } \\
\text { resimler (gif) }\end{array}$ & $\begin{array}{c}\text { MEF } \\
\text { Üniversitesi } \\
\text { Kütüphanesi }\end{array}$ & Evet & $\begin{array}{c}\text { Bağlantı } \\
\text { linkleri } \\
\text { Videolar } \\
\text { Fotoğraflar } \\
\text { Hareketli } \\
\text { resimler (gif) } \\
\text { Anket }\end{array}$ \\
\hline $\begin{array}{c}\text { Waseda } \\
\text { Üniversitesi } \\
\text { Kütüphanesi }\end{array}$ & Hayır & $\begin{array}{l}\text { Bağlantı } \\
\text { linkleri } \\
\text { Fotoğraflar }\end{array}$ & $\begin{array}{c}\text { Bilkent } \\
\text { Üniversitesi } \\
\text { Kütüphanesi }\end{array}$ & Evet & $\begin{array}{c}\text { Bağlantı } \\
\text { linkleri } \\
\text { Videolar } \\
\text { Fotoğraflar } \\
\end{array}$ \\
\hline
\end{tabular}

Tablo 6. Twitter içerikleri (1 Şubat 2020-18 Haziran 2020)

\begin{tabular}{|c|c|}
\hline Yurtdışı Üniversite Kütüphaneleri & Yurtiçi Üniversite Kütüphaneleri \\
\hline $\begin{array}{l}\text { * Covid'19 ile ilgili paylaşımlar yapmışlar, bu konu ile ilgili } \\
\text { öneriler sunmuşlardır. } \\
\text { * Bağlı oldukları üniversitenin pandemi süreci ile ilgili } \\
\text { hazırladıkları bağlantıları, güncellemeleri Twitter hesaplarında } \\
\text { kullanmışlar ve yayınlamışlardır. } \\
\text { * Twitter hesaplarında takipçilerini rahatlatıcı, kütüphaneye } \\
\text { bağlayııı, kendilerini ve kaynaklarını unutturmayan } \\
\text { paylaşıılarda bulunmuşlardır. } \\
\text { * Paylaşımlarında bağlantı linkleri, videolar, fotoğraflar, } \\
\text { resimler, hareketli resimler (gif) kullanarak paylaşımlarının } \\
\text { etkisini artırmaya çalışmışlardır. } \\
\text { * “Kullanıcı odaklı” bir yaklaşım ile paylaşımlar yapmışlardır. } \\
\text { * Paylaşımlarında \#etiket kullanarak bahsettikleri konuların } \\
\text { daha fazla kişiye ulaşmasını sağlamışlardır. } \\
\text { * Kütüphane personeline yönelik etkinliklerin paylaşımları } \\
\text { yapılarak, personelin kendini değerli hissetmesi sağlanmıştır. }\end{array}$ & $\begin{array}{l}\text { * Covid'19 ile ilgili paylaşılan bilgiler daha çok } \\
\text { elektronik kaynaklara yönelik bilgilerdir. } \\
\text { * Kullanıcıların kütüphane hizmetleri hakkında } \\
\text { pandemi boyunca yeterince bilgilendirilmedikleri } \\
\text { gözlemlenmiştir. } \\
\text { * Paylaşımlarında bağlantı linkleri, videolar, } \\
\text { fotoğraflar, resimler, hareketli resimler (gif) } \\
\text { kullanarak paylaşıllarının etkisini artırmaya } \\
\text { çalışmışlardır. } \\
\text { * Anket yayınlayarak kullanıcı görüş̧lerine verilen } \\
\text { önemi göstermişlerdir. } \\
\text { * Paylaşımlarında \#etiket kullanarak bahsettikleri } \\
\text { konuların daha fazla kişiye ulaşmasını sağlamışlardır. } \\
\text { * "Kullanıcı odaklı" bir yaklaşım ile paylaşımlar } \\
\text { yapmışlardır. } \\
\text { * Paylaşımlarında \#etiket kullanarak bahsettikleri } \\
\text { konuların daha fazla kişiye ulaşmasını sağlamışlardır. } \\
\text { * Kütüphane personeline yönelik etkinliklerin } \\
\text { paylaşımları yapılarak, personelin kendini değerli } \\
\text { hissetmesi sağlanmıştır. }\end{array}$ \\
\hline
\end{tabular}




\section{SONUÇ ve ÖNERILER}

COVID-19 küresel salgını ile insanoğlu fiziksel ve psikolojik zorlukların bulunduğu oldukça zor bir süreçten geçmektedir. Bu, Dünya çapında "kültür ve bilgi” kavramlarının, bilgiyi taşıyan ve aktaranların ne kadar önemli ve değerli olduğunun yaşayarak fark edildiği bir süreç olmuştur.

Salgın döneminde 'yeni normal' düzenin temelini dijital, teknolojik bir hayat ele geçirmiştir. Eğitimden iş yaşamına, sosyal ilişkilerden alışverişe, müze, kütüphane ziyaretlerine kadar çoğu aktivite sanal olarak gerçekleştirilmekte ve artık bu sanal aktivitelerin çoğu yeni normal olarak kabul edilmektedir. Bundan sonra kütüphanelerin toplumla olan ilişkisinde bu değişimin önemli rol oynayacağı anlaşılmaktadır. Bu bağlamda, sosyal medya da kütüphanelerde değişime ivme sağlayan araçlardan biri haline gelmiştir. Kütüphane sosyal medya uygulamaları doğru amaçlar için ve kaliteli hizmet anlayışı ile kullanıldığı takdirde, bilgi alma ve öğrenme sürecinde toplumlardaki her kesiminin kolaylıkla yararlanabileceği firsatlar sunmaktadır. İyi yönetilen kütüphane sosyal medya uygulamaları, hizmetler açısından farkındalık ve bilgi sahibi olmak isteyen herkesin zaman ve mekândan bağımsız olarak istediği bilgi hizmetini alabilmesi olanakları sağlamaktadır.

Günümüze kadar geliştirilen kütüphane sosyal medya uygulamaları incelendiğinde, ülkemizde bu hizmetlerin henüz gelişim sürecinin başlangıç aşamalarında olduğu görülmektedir. Kütüphanelerin sosyal medya kullanımı, gelecekte kütüphanelerin ne tür hizmetler üretmesi gerektiğine işaret etmesi ve bilişim teknolojilerine uyumlu çağdaş hizmetler üretebilen kurumlardan olduklarını göstermeleri bakımından önemli araçlardan biridir. "Bu firsatı zamanlı ve uygun şekilde değere dönüştürebilen kütüphaneler diğerlerine fark atarak nitelikli hizmet üretme avantajına sahip olmayı sürdürebileceklerdir” (Odabaş, 2009, s. 56).

Salgının başlangıcından itibaren üniversite kütüphanelerinin sosyal medya aracılı̆̆ ile üç şeyi yapmayı hedeflediği anlaşılmaktadır. Bunlar: (1) önleyici tedbirlerle ilgili bilgileri oluşturarak ve yayarak halk sağlı̆g 1 bilincini desteklemek, (2) son gelişmeler, araştırmalar ve literatür hakkında bilgi vererek toplumun her kesiminden araştırmacıları ve öğretim üyelerini desteklemek ve (3) kullanıcıları için rutin temel kütüphane hizmetleri sağlamak.

Çalışma sonuçları, Twitter'ın en yaygın kullanılan platformlardan biri olduğunu, ağırlıklı olarak kütüphane çalışmaları ile ilgili duyuruların paylaşılması ve etkinliklerin tanıtımı için kullanıldığını göstermiştir. COVID-19 karantinası sırasında kütüphaneler, hizmetlerinin çoğunu çevrimiçi hale getirerek yeni koşullara hızla yanıt vermiştir. Ancak sosyal medyayı hizmet sunumu için tam olarak kullanmamışlar, sosyal medyayı statik bir iletişim kanalı olarak kullanmışlardır. Kütüphanelerden yalnızca birkaçı, zamanında ve güvenilir bilgi sağlayarak halk sağlığının geliştirilmesindeki rollerini vurgulama firsatını yakalamıştır. 
Hizmet tanıtımı ve erişim için sosyal medyanın gücünden yararlanmak isteyen kütüphane yöneticileri, platform popülerliğini, mevcut sosyal medya eğilimlerini, kullanıcı tercihlerini ve kütüphanelerinin özel tanıtım hedeflerini dikkate alan bir strateji oluşturmalıdır (Koulouris ve diğerleri, 2021, s. 19). Ancak, literatürdeki kanıtlar, sosyal medyayı kullanan birçok kütüphanenin faaliyetlerine yön verecek bir politikasının olmadığını göstermektedir. Bu nedenle, sosyal medyayı benimseyen kütüphaneler, sosyal medyayı günlük kullanımlarını desteklemek için politikalar tasarlamayı düşünmelidir. Politika, kütüphanelerin sosyal medya pazarlamasının sorunlu yönleriyle başa çıkmak için alabileceği önlemin ana hatlarını verecektir. Politika, yönetimde yer alan rollerin, sorumlulukların ve günlük aktivitelerin ana hatlarını çizerek sosyal medyanın yönetimi için yapı oluşturmaya yönelik temel kuralları tanımlar (Ihejirika, 2020, s. 132). Akademik kütüphaneler, hizmet ve kaynaklarına çoklu erişimi sağlamak için daha fazla sosyal medya aracını entegre etmeli, fakülte üyeleri ve öğrenciler tarafindan kütüphane çevrim içi kaynaklarının tam olarak kullanılmasını sağlamak için web seminerleri, gelişmiş web sayfası ve sosyal medyayı içeren agresif bir pazarlama planı geliştirmelidir (Okonoko ve diğerleri, 2020, s. 245 ; Pryce ve diğerleri, 2021, s. 16).

Üniversite kütüphanelerinde sosyal medya hesaplarının daha etkin ve verimli kullanılabilmesi için bu hesapları yöneten kişilerin halkla ilişkiler, sosyal medya ve pazarlama konularında eğitim almaları yararlı olacaktır. Ayrıca, üniversitelerde meslek elemanı yetiştiren bölümlerin ders programlarına sosyal medyanın kullanıma yönelik konuların eklenmesi, kütüphane ve bilgi merkezlerinde sanal dünyayı doğru yönetebilecek kişilerin yetişmesine altyap1 oluşturacaktır (Biçen Aras ve Çolaklar, 2013, s. 214; Biçen Aras, 2019b).

Kütüphaneciler zamana ayak uydururken yeni beceriler edinmek durumundadır. Sosyal medyayı etkili bir şekilde kullanmak da akademik kütüphane personelinden beklenen kritik 21. yüzyıl becerileri arasında görülmektedir (Chawner ve Oliver, 2013, s. 29). Bu nedenle bilgi merkezleri için bu alanda eğitim almış, kendini geliştirmiş "sosyal medya kütüphanecilerine" ihtiyaç vardır.

Her krizde bir bilgi ihtiyacı vardır; ister COVID-19 için isterse başka olağan dışı durumlar için olsun, kütüphaneciler ve bilgi uzmanları bu ihtiyacı karşılamaya hazır olmalıdır. Sosyal mesafe, COVID-19'un yayılmasını önlemenin iyi bir yolu olsa da, kullanıcılara bilgi erişimi sağlamak, bilgi profesyoneli olan kütüphanecilerin sosyal sorumluluğu olmaya devam etmektedir.

Library, Archive and Museum Research Journal, 2022, 3(1), 1-26 


\section{KAYNAKÇA}

Abdullah, N., Chu, S., Rajagopal, S., Tung, A. and Kwong-Man, Y. (2015), “Exploring libraries' efforts in inclusion and outreach activities using social media", Libri, Vol. 65 No. 1, pp. 34-47.

Adeoye, A. A., Onuoha, C., Obiano, D. C., \& Motunrayo, O. (2021). Social Media As A Collaborative Tool For Research Among Library And Information Science (Lis) Professionals In Nigeria. Library Philosophy and Practice (e-journal). https://digitalcommons.unl.edu/libphilprac/5137/

Adetayo, A. J., \& williams-ilemobola, O. (2021). Librarians' generation and social media adoption in selected academic libraries in Southwestern, Nigeria. Library Philosophy and Practice (e-journal).

https://digitalcommons.unl.edu/libphilprac/4984/

Anderson, K. E. (2020, February 10). Getting acquainted with social networks and apps: talking about TikTok. Library Hi Tech News, 37(4), 7-12. https://doi.org/10.1108/LHTN-01-2020-0001

Arapasopo, E. A., \& Adekoya, C. O. (2021, August 9). Library leadership in Nigeria and COVID-19 pandemic. Information Discovery and Delivery, ahead-of-print(ahead-of-print), 10. https://doi.org/10.1108/IDD-03-20210027

Arıkan, A. (2009). Yeni bir disiplinlerarası oluşum niteliğiyle bilgi ve inovasyon yönetimi (MBA) yüksek lisans programı: Bir olgu incelemesi. A. Yıldızeli, A. Arıkan ve T. Çakmak (Ed.), Bilgi Çağında Varoluş: "Fırsatlar ve Tehditler" Sempozyumu, ÜNAK 2009, 01-02 Ekim 2009, Yeditepe Üniversitesi, İstanbul, Bildiri Kitab1 (s.1529). Ankara: Üniversite ve Araştırma Kütüphanecileri Derneği.

Ayık, K. (2019). Arşivlerin Tanıtımsal Pazarlama Çalışmalarında Web Ve Sosyal Medya Araçlarının Kullanılması: Kadın Eserleri Kütüphanesi Ve Bilgi Merkezi Vakfı Örneği. Bilgi ve Belge Araştırmaları Dergisi, (12), 33 - 61. https://dergipark.org.tr/tr/download/article-file/907388

Bashorun, M., Babaginda, B., Bashorun, R. B., \& Sowemimo, I. (2021). Transformation of Academic Library Services in Coronavirus Pandemic Era: The New Normal Approach. Journal of Balkan Libraries Union, 8(1), 4250. https://dergipark.org.tr/tr/download/article-file/1669730

Biçen Aras, B. (2019). Üniversite Kütüphanelerinde İletişim Ve Öğretim İçin Sosyal Medya "\#MEFteKütüphane" [III. OTURUM: Sosyal Medyada Fark Yaratan Kütüphaneler: GIBB19 Gelecek İçin Bilgi Çalıştayı "Bilginin Dönüşümü 2019", Belek, Antalya] [pdf]. MEF Üniversitesi Kütüphanesi Akademik Arşiv. Retrieved Kasım 20, 2021, from https://openaccess.mef.edu.tr/xmlui/handle/20.500.11779/1150

Biçen Aras, B., \& Çolaklar, H. (2013). Üniversite kütüphanelerinde Twitter'ın sosyal medya aracı olarak kullanımı. In G. Güneş, N. Özel, \& T. Çakmak (Eds.), Bilgi Sistemleri Platformlar, Mimariler ve Teknolojiler, ÜNAK 2013 Konferans, 19-21 Eylül 2013, İstanbul, Bildiri Kitab1 (pp. 192-215). Üniversite ve Araştırma Kütüphanecileri Derneği.

Boztepe Taşkıran, H. (2021, Mayıs). Kültür ve sanat iletişimi bağlamında müzelerin sosyal medyaya adaptasyonu: Devlet ve özel müze kullanımlarını karşılaştırmaya yönelik bir araştırma. İNİF E- Dergi, 6(1), 11 31. https://doi.org/10.47107/inifedergi.865697

Çakmak, T., \& Eroğlu, Ş. (2020). Public libraries on Facebook: content analysis of Turkish public libraries' posts. Library Hi Tech, 39(2), 602-624. https://doi.org/10.1108/LHT-04-2020-0082 
Chawner, B., \& Oliver, G. (2013). A survey of New Zealand academic reference librarians: Current and future skills and competencies. Australian Academic \& Research Libraries, 44(1), 29-39. https://doi.org/10.1080/00048623.2013.773865

Chisita, C. T., \& Chizoma, U. S. (2021, March 22). Rethinking academic library space amidst the COVID-19 pandemic in South Africa: preparing for the future. Information Discovery and Delivery, 49(2), 105-113. https://doi.org/10.1108/IDD-07-2020-0087

Choi, Y., \& Kim, S. U. (2021, November 10). Public library Twitter use during the early period of the COVID-19 lockdown in the United States. The Electronic Library, 39(5), 713-731.

Data Never Sleeps 9.0. (2021). Domo. Retrieved December 13, 2021, from

https://www.domo.com/learn/infographic/data-never-sleeps-9

Degenhard, J. (2021, Jul 20). Social media users in Turkey 2017-2025. Forecast of the number of social media users in Turkey from 2017 to 2025. Retrieved Kasim 11, 2021, from https://www.statista.com/forecasts/1144933/social-media-users-in-turkey

Eriksson, M. (2018, Ağustos 30). Lessons for Crisis Communication on Social Media: A Systematic Review of What Research Tells the Practice. International Journal of Strategic Communication, 12(5), 526-551. https://doi.org/10.1080/1553118X.2018.1510405

Goedert, K. H. (2021, Ağustos 3). \#PowerInNumbers: How Digital Libraries Use Collaborative Social Media Campaigns to Promote Collections. Journal of Web Librarianship, 15(4), 195-218. https://doi.org/10.1080/19322909.2021.1959487

Hollebeek, L. D. (2013, February 1). The Customer Engagement/Value Interface: An Exploratory Investigation. Australasian Marketing Journal, 21(1), 17-24. https://doi.org/10.1016/j.ausmj.2012.08.006

Ihejirika, K. T. (2020, November). Social Media Strategies for Marketing in University Libraries: Undergraduate User Attitudes and Motivation for Engagement [Doktora tezi].

ResearchArchive • Te Puna Rangahau. Retrieved Kasim 21, 2021, from https://researcharchive.vuw.ac.nz/xmlui/bitstream/handle/10063/9426/thesis_access.pdf?sequence=1

Ilyas, H., Anwar, A., Yaqub, U., Alzamil, Z., \& Appelbaum, D. (2021, June 8). Analysis and visualization of COVID-19 discourse on Twitter using data science: a case study of the USA, the UK and India. Global Knowledge, Memory and Communication, ahead-of-print(ahead-of-print), 1-15. https://doi.org/10.1108/GKMC01-2021-0006

Johnson, J. (2021, September 10). Worldwide digital population as of January 2021. Global digital population as of January 2021. Retrieved Kasim 12, 2021, from https://www.statista.com/statistics/617136/digital-populationworldwide/

Kahmann, K., \& Fingerle, B. (2021, August 24). Why Libraries Have to be Permanently Active on Social Media: 7 "Glorious" Reasons - 2021 Update. ZBW MediaTalk. Retrieved November 21, 2021, from https://www.zbwmediatalk.eu/2021/08/why-modern-libraries-have-to-be-active-on-social-media-seven-glorious-reasons/

Library, Archive and Museum Research Journal, 2022, 3(1), 1-26 
Kemp, S. (2021, February 11). Digital 2021: Turkey. Datareportal. Retrieved Kasim 16, 2021, from https://datareportal.com/reports/digital-2021-turkey

Koulouris, A., Vraimaki, E., \& Koloniari, M. (2021). COVID-19 and library social media use. Reference Services Review, 49(1), 19-38. https://doi.org/10.1108/RSR-06-2020-0044

Kurt, E. V. (2021, Mayıs 19). Sağlık İletişimi ve Sosyal Medya: Sivil Toplum Kuruluşlarının Twitter Kullanımı Üzerine Bir Değerlendirme. Manisa Celal Bayar Üniversitesi Sosyal Bilimler Dergisi, İstiklal Marş1 100. Y1l Armağan Sayıs1, 19, 89-109. https://doi.org/10.18026/cbayarsos.649858

Kushniryk, A., \& Orlovb, S. (2021, April 15). 'Follow us on Twitter': How public libraries use dialogic communication to engage their publics. Library \& Information Science Research, 43(2), 1-7. https://doi.org/10.1016/j.lisr.2021.101087

Li, L., Zhang, Q., Zhang, J., Wang, T., Gao, T.-L., Duan, W., Tsoi, K. K., \& Wang, F.-Y. (2020, March 20). Characterizing the Propagation of Situational Information in Social Media During COVID-19 Epidemic: A Case Study on Weibo. IEEE Transactions on Computational Social Systems, 7(2), 556-562.

https://doi.org/10.1109/TCSS.2020.2980007

Liu, C., Tian, Q., \& Zhu, X. (2021). Social media emergency information assessment of major emergencies: a case study of additional emotional characteristics. Library Hi Tech, ahead-of-print(ahead-of-print). https://doi.org/10.1108/LHT-08-2021-0288

Martínez-Cardama, S., \& Pacios, A. R. (2020). Twitter communication of university libraries in the face of Covid-19. Profesional de la información, 29(6), 1-15. https://doi.org/10.3145/epi.2020.nov.18

Martzoukou, K. (2021, May 20). Academic libraries in COVID-19: a renewed mission for digital literacy. Library Management, 42(4/5), 266-276. https://doi.org/10.1108/LM-09-2020-0131

Mnzava, E. E. (2021). Twitter library account: highlights for the users and librarians. Library Hi Tech News, (2), 8-10. https://doi.org/10.1108/LHTN-07-2020-0064

Muhammad, A., \& Zhiwei, T. (2021, November 23). Social media and library marketing. Library Hi Tech News, ahead-of-print No(ahead-of-print No). https://doi.org/10.1108/LHTN-09-2021-0056

Muñoz-Expósito, M., Oviedo-García, M. Á. O.-G., \& Castellanos-Verdugo, M. (2017, October 2). How to measure engagement in Twitter: advancing a metric. Internet Research, 27(5), 1122-1148. https://doi.org/10.1108/IntR-06-2016-0170

Naeem, S. B., \& Bhatti, R. (2020, June 13). The Covid-19 'infodemic': a new front for information professionals. Health Information and Libraries Journal. https://doi.org/10.1111/hir.12311

Odabaş, H. (2009). Mobil öğrenmeden mobil kütüphaneye. A. Yıldızeli, A. Arıkan ve T. Çakmak (Ed.), Bilgi Çağında Varoluş: "Fırsatlar ve Tehditler" Sempozyumu, ÜNAK 2009, 01-02 Ekim 2009, Yeditepe Üniversitesi, İstanbul, Bildiri Kitabı (s. 1-7). Ankara: Üniversite ve Araştırma Kütüphanecileri Derneği. 
Okike, B. I. (2020). Information dissemination in an era of a pandemic (COVID-19): librarians. Library Hi Tech News, 37(9), 1-4. https://doi.org/10.1108/LHTN-04-2020-0040

Okonoko, V. N., Abba, M. A., \& Arinola, A. E. (2020, July-December). Users' Expectation of Library Services and Resources in the COVID 19 Pandemic Era: A Comparative Study of Two Academic Libraries in Nigeria. Library Progress (International), 40(2), 236-246. https://doi.org/10.5958/2320-317X.2020.00027.6

Oxford University Press. (2020, February 10). 10 tips for librarians: embedding social media good practice in your everyday work. Library Journal. Retrieved November 21, 2021, from https://www.libraryjournal.com/?detailStory=10-tips-for-librarians-embedding-social-media

Pryce, T. L., Russell, J., Crawford, M. N., McDermott, J. O., Christina, A., \& Perkins, N. (2021, September 16). Experiences, perspectives, and emerging frameworks: COLINET libraries response to the COVID-19 pandemic. Global Knowledge, Memory and Communication, ahead-of-print(ahead-of-print).

https://doi.org/10.1108/GKMC-03-2021-0055

Rafiq, M., Batool, S. H., Ali, A. F., \& Ullah, M. (2021, January). University libraries response to COVID-19 pandemic: A developing country perspective. The Journal of Academic Librarianship, 47(1), 1-10. https://doi.org/10.1016/j.acalib.2020.102280

Samur, S. (2020). Covid-19 Pandemi Sürecinde Ankara'daki Devlet Üniversitelerinin Instagram Kullanımları Üzerine Nicel Bir Araştırma. ASEAD Avrasya Sosyal ve Ekonomi Araştırmaları Dergisi (ASEAD) Eurasian Journal of Researches in Social and Economics (EJRSE), 7(6), 436-457. https://dergipark.org.tr/tr/download/article-file/1168056

Shabani, A., \& Keshavarz, H. (2021). Media literacy and the credibility evaluation of social media information: students' use of Instagram, WhatsApp and Telegram. Global Knowledge, Memory and Communication, aheadof-print no(ahead-of-print no). https://doi.org/10.1108/GKMC-02-2021-0029

Sobré-Denton, M. (2015, January 27). Virtual intercultural bridgework: social media, virtual cosmopolitanism, and activist community-building. New Media \& Society, 18(8), 1715-1731.

https://doi.org/10.1177/1461444814567988

Statista Research Department. (2021, Agust 13). Turkey: social media penetration 2017-2026. Social network user penetration in Turkey from 2017 to 2026. Retrieved Kasim 11, 2021, from https://www.statista.com/statistics/567417/predicted-social-network-user-penetration-rate-in-turkey/

Sy, L., \& Chen, C. (2021, November 15). Everything Marketers Should Know About the Fastest-Growing Audience Demographic on LinkedIn. LinkedIn. Retrieved November 20, 2021, from https://www.linkedin.com/business/marketing/blog/trends-tips/everything-marketers-should-know-about-thefastest-growing-audience-demographic-on-linkedin

Şahinsoy, K. (2017). Kriz yönetimi açısından geleneksel ve sosyal medya. İstanbul Aydın Üniversitesi Dergisi, 9(4), 1-19. https://doi.org/10.17932/IAU.IAUD.13091352.2017.9/36.1-19

Taylor and Francis Group (2014), "Use of social media by the library: current practices and future opportunities",

Library, Archive and Museum Research Journal, 2022, 3(1), 1-26 
Bezirci, P.ve Biçen Aras, B.

Taylor and Francis White Papers, doi: 10.6084/m9.figshare.1221673.v1.

Valentini, C., Romenti, S., \& Kruckeberg, D. (2017). Handling Crises in Social Media: From Stakeholder Crisis Awareness and Sense-making to Organizational Crisis Preparedness (L. Austin \& Y. Jin, Eds.). In (pp. 57-67).

Routledge. 978-1-315-74906-8

Winata, A. P., Fadelina, R., \& Basuki, S. (2021, April 7). New normal and library services in Indonesia: a case study of university libraries. Digital Library Perspectives, 37(1), 77-84. https://doi.org/10.1108/DLP-07-20200059

Yang, S., \& Ju, B. (2021, January). Library support for emergency management during the time of natural disasters: Through the lens of public library Twitter data. Library and Information Science Research, 43(1), 1-10. https://doi.org/10.1016/j.lisr.2021.101072

Yanık, O. K., \& Becan, C. (2019, Nisan 1). Yeni İletişim Ortamlarında Kriz İletişimi: Volkswagen ve Burger King Krizleri Üzerine Bir İnceleme. Aydın Üniversitesi İletişim Çalışmaları Dergisi, 5(1), 59-74. https://dergipark.org.tr/tr/pub/icd/issue/52710/695160 